\title{
Türkiye'de Fen Bilimleri Dersi Öğretiminde Bilimsel Öyküleme Yöntemine Yönelik Yapılan Çalıșmaların İçerik Analizi
}

\author{
Sinan Çınar ${ }^{1}$, \& Busra Gerz ${ }^{2}$
}

Özet: Son yıllarda, fen bilimleri öğretim programlarında, fen okuryazar bireyler yetiştirmenin hedeflenmesiyle birlikte sınıflarda bilimsel öyküleme yönteminin kullanılmaya başlaması dikkat çekmiştir. Bu araştırmada Türkiye'de fen bilimleri öğretiminde bilimsel öyküleme yöntemi üzerine yapılan çalı̧maların genel özellikleri (yayın yıll, yazar sayısı, yayın türü) ve içerik özellikleri (hikâye türleri, amaç, yöntem, veri toplama aracı, veri toplama araçlarının sayısı, çalışma grubu, sonuç ve öneriler) açısından incelenmesi amaçlanmıştır. Araştırma nitel araştırma yöntemlerinden durum çalışması şeklinde desenlenmiştir. Araştırma sonucunda, çalışmaların son yıllarda genel olarak yayınlanmış olması dikkat çekicidir. Bazı araştırmalarda bilimsel öyküleme yönteminin sınıf ortamlarında uygulanması için ders kitaplarının içeriğinin geliştirildiği ve öğretim programlarıyla bütünleştirildiği görülmüştür. Ayrıca, yapılan çalışmaların çoğunda pozitif sonuçların elde edildiği, bilimsel öyküleme yönteminin fen öğretimiyle bütünleştirilmesi gerektiği sonucuna varılmıştır. Elde edilen sonuçlara bağlı olarak, fen derslerinde bilimsel öyküleme yöntemi kullanılarak öğrencilerin fen okuryazar bireyler olmasını sağlayan öğretim programlarının tasarlanıp uygulanabileceği söylenebilir.

Anahtar Kelimeler: Bilimsel Öyküleme, Betimsel Analiz, Araştırma Eğilimleri

Geliş Tarihi: 16.12.2019 - Kabul Tarihi: 01.05.2020 - Yayın Tarihi: 29.06.2020

DOI: $10.29329 /$ mjer.2020.258.8

\section{Content Analysis of Scientific Storytelling Methods in Science Teaching in Turkey}

\begin{abstract}
In recent years, with the aim of educating science literate individuals in science teaching programs, it has attracted attention that scientific storytelling method has been used in classrooms. In this study, general characteristics of the studies on scientific narrative methods in science education in Turkey (the year of publication, number of authors, publication type) and properties of the content (the topics of the history, objectives, methods, data collection tool, the number of data collection tools, working group results and recommendations). The research is designed as a qualitative case study. As a result of the research, it is noteworthy that the studies have been published in general in recent years. In some studies, it has been seen that the content of the textbooks has been developed and integrated with the curriculum for the application of the scientific narrative method in classroom settings. In addition, it was concluded that positive results were obtained
\end{abstract}

\footnotetext{
${ }^{1}$ Sinan Çınar, Assist. Prof. Dr., Temel Eğitim Bölümü, Recep Tayyip Erdoğan Üniversitesi Eğitim Fakültesi, ORCID: 0000-0002-5208-8986

Correspondence: sinan.cinar@erdogan.edu.tr

${ }^{2}$ Busra Gerz, İlköğretim Bölümü, Recep Tayyip Erdogan Üniversitesi, ORCID: 0000-0001-8939-1607
} 
in most of the studies and scientific narration method should be integrated with science education. Depending on the results obtained, it should be said that using the scientific narrative method in science courses, the curriculum that enables students to be science literate individuals can be designed and implemented.

Keywords: Scientific Narrative, Descriptive Analysis, Research Trends.

\section{GİRİS}

Günümüzde bilim alanında yapılan çalışmalar bilgiye ulaşımı kolaylaştırırken teknoloji ile birlikte toplumların yapısında bir takım değişime yol açar. Bu değişim geleceğimiz olan çocukların eğitim öğretim yaşantılarının şekillenmesinde rol oynamakta ve bunu eğitim programları yoluyla sağlamaktadır (Yar, 2017). Günümüz eğitim programlarının vizyonu da bu bağlamda şekillenmiştir. Yeni ilköğretim programına göre Milli Eğitim Bakanlığı (MEB, 2018), "Bireysel farklılıkları ne olursa olsun bütün öğrenciler fen okuryazarı olarak yetişmelidir. Fen okuryazarlı̆ğ, bireylerin sorgulama, araştırma, eleştirel düşünme, problem çözme, karar verme becerilerini geliştirir’. Ayrıca öğretim programları, öğrencilerin fen bilimleri kapsamında hazırlanan akademik çalışmalara ulaşmalarını ve alandaki gelişmeleri takip edebilmek için gerekli bilimsel bilgiyi edinmelerini sağlamalıdır (akt. Kuş, 2014). Uygun teknik ve öğrenme araçlarıyla zenginleştirilmiş öğrenme ortamlarında dikkati üzerinde toplayan ve öğrencilere önceki zamanlardan aşina gelen hikâyeleri sürece katmak fen bilimleri öğretiminde etkili öğrenme sağlar. Öğrencilerin okudukları veya karşılaştıkları durumlar sonucunda yaptıkları çıkarımlarının doğruluğu fen okuryazarı bireyler olabilmeleri için önem arz eder (Pekmezci, 2014).

Bireylerin çevrelerinde gördükleri olayları veya durumları anlamlandırırken bilimsel bir bakış açısı ile yaklaşması onları fen ile ortak bir noktada buluşturur. Fenin bilimsel içeriği öğrenciler için çoğu zaman soyut ve anlamlandırılması zor olarak görülmüştür. Bu nedenle öğrenciler fen bilimleri için olumsuz tutum geliştirip, fenden soğuyabilmektedir (Gölcük, 2017). Bu açıdan zor ve soyut görünen kavramların öğretiminde süreci olumlu hale getirecek yöntem ve teknikler tercih edilmelidir. Yılmaz'a göre (2013) uygulanan yöntem ve teknikler dersi eğlenceli hale getirmeli, öğrencilerde merak duygusu uyandırmalı ve öğrencilerin dersi içselleştirebilmelerini sağlamalıdır. Program içeriğinde yer alan bilgiler uygulama boyutuna çıkamadığ $\mathrm{Bu}$ nedenle geliştirilen öğrenme araçlarının öğrencilerin kendilerini ifade edebilmelerine olanak sunması, kendi yaşantıları içerisinde bu kavramları bulabilmesi ve fen bilimlerine karşı ilgiyi artırıp öğrenme isteği uyandırması gerekmektedir (Demircioğlu, Demircioğlu ve Ayas, 2006). Fen bilimleri öğretiminde bunu sağlayacak öğrenme araçları da bilimsel öykülerdir.

Bilimsel öyküler bilimsel olay, durum ve kavramları konu alan okuyucularda bilim insanlarının yaşamları hakkında merak uyandıran öykülerdir (Coşkun, 2012). Şen-Gümüş’e göre (2009) bilimsel öyküler öğrencilerin öykünün ana karakterinin rolüne bürünüp öğrendiklerini uzun süre hafızalarında 
saklayabilmelerine ve karakterin ruhuyla doğru yanlışı da ayırt edebilmelerine olanak sağlayan öykülerdir. Milne 'e göre (1998) ise bilimsel öyküler bilimsel kültür kavramının aktarımını sağlarken ve aynı zamanda bilimin doğası hakkında bir şeyler ortaya koyar. Ayrıca araştırmacıya göre bilimsel öyküler konularına göre şu şekilde sınıflandırılabilir;

1. Bilimsel kahramanlık öyküleri

2. Bilimsel keşif öyküleri

3. Tanıtıcı bilim öyküleri

4. Politik açıdan doğrulayıcı bilim öyküleri

Kısaca bu bilimsel öykü türlerini açılayacak olursak; bilimsel kahramanlık öyküleri, bilim alanında gelişim sağlayan bilim kahramanlarının yaşantılarını anlatır. Bilimsel keşif öykülerinde ise bilimsel bilgiye tesadüfen ulaşıldığından bahsedilir. Diğer bir bilimsel öykü türü tanıtıcı bilim öykülerinde, kavramların bilimsel açıdan ele alınıp incelendiği ve bilimin doğada her yerde olduğu üzerine vurgu yapılır. Politik açıdan doğrulayıcı bilim öyküleri ise, günlük yaşamdaki olayları insanların kültür, inanç, ırk gibi farklılıklarını göze alarak ele alır ve bilimin sosyo politik açıdan etkilerini konu edinir (Milne, 1998). Görüldüğü tüm bilimsel öykü türleri öğrencilerin konular hakkındaki ön bilgilerini harekete geçirip yeni bilgileri yapılandırırken zihinlerinde oluşan kavram yanılgılarını da düzeltme imkânı sunar (Tao, 2002).

$\mathrm{Bu}$ bağlamda son yıllarda araştırmacılar bilimsel öykülerle fen bilimleri öğretiminde öğrencilerin bilime yönelik ilgilerini, algılarını, tutumlarını ve bilim insanı imajlarını belirlemeye çalışmışlardır (Driver, Asoko, Leach, Mortimer ve Scott, 1994). Bunun yanı sıra bazı araştırmacılar çalışmalarında bilimsel öyküleri ölçme ve değerlendirme sürecinde kullanırken (Case, 1997; Taşar, 2006; Polat, 2011) bazı araştırmacılar da öğretim materyali olarak kullanmayı tercih etmişlerdir (Roach, 1993; Chun, 2000). Diğer taraftan bilimsel öyküleme yönteminin fen bilimleri öğretimine yeni kazandırılmış bir yöntem olduğu ve bu sebeple alanla ilgili çalışmaların sınırlı sayıda olduğu söylenebilir.

Tablo 1'de görüldüğü gibi, fen bilimleri öğretiminde bilimsel öyküleme yönteminin kullanımıyla ilgili araştırmaların çoğu, öğrencilerin, öğretmen adaylarının, öğretmenlerin ve eğitimcilerin alg1 ve görüşlerini incelemiştir. Fen bilimleri öğretiminde bilimsel öyküleme yönteminin kullanımını geliştirmek için birçok teorik araştırma çalışmaları yapıldığı söylenebilir. Bazı çalışmalar bilimsel öyküleme yöntemini tanıtmış ve sınıf içi uygulama etkinliği örnekleri olarak araştırmıştır. Ayrıca, bilimsel öykülerin bilimin doğası üzerindeki etkilerini belirlemek için deneysel çalışmalar yapılmıştır. Öğretmenlerin uygulamalarını doğrudan inceleyen nitel araştırmalarla karşılaşmak mümkündür. Bununla birlikte, fen bilimleri öğretiminde bilimsel öyküleme konusunda yapılan tematik bir incelemeyle karşılaşılmamıştır. $\mathrm{Bu}$ nedenle, bu araştırma literatüre araştırmacılara yönelik, öğrencilere, eğitimcilere, ailelere, öğrenme ortamlarına bilimsel öyküleme yönteminin dahil 
edilmesine dair farklı şekillerde katkı sağlayacak ve yukarıda incelenen tüm çalışmalar gibi bundan sonra yapılacak araştırmalara 1şık tutacaktır.

Tablo 1. Fen bilimleri öğretiminde ilgili literatür

\begin{tabular}{ll}
\hline Araştırmanın kapsamı & Literatürde yürüttülen çalışmalar \\
\hline & Bertiz, 2005; Gür ve Haktanır, 2007; Sen Gümüş, 2009; Karaçam, \\
& Aydın ve Digilli, 2014; Polat, 2011; Coşkun, 2012; Akgül, Geçikli \\
$\begin{array}{l}\text { Öğrencilerin, öğretmen adaylarının, } \\
\text { öğretmenlerin ve eğitimcilerin } \\
\text { görüşlerinin araştırılması }\end{array}$ & ve Doğan, 2017; Gölcük, 2017; Unat, 2017; Zengin, 2018; Zengin ve \\
\hline
\end{tabular}

Çalışmada Türkiye'de fen bilimleri öğretiminde bilimsel öyküleme yöntemine yönelik yapılan çalışmaların yayınlandığı yıl, yayın türü, yazar sayısı, yöntem özellikleri, hikâye türleri, veri toplama araçları, veri toplama araçlarının sayısı, çalışma grupları, sonuçları ve önerileri incelenip, bunun sonucunda araştırmacıların eğilimlerinin hangi yönde olduğunu tespit edilmeye çalışılmıştır. Araştırmada yönelimin hangi yönde olduğunu ortaya çıkaran sorular aşağıdaki gibidir:

- Çalışmaların genel özelliklerine göre dağılımı (yıl, yazar, yayın türü) nedir?

- Çalışmaların içeriklerinin özelliklerine göre dağılımı (hikâye türleri, amaçları, yöntemleri, veri toplama araçları, veri toplama araçlarının sayısı, çalışma grubu, sonuçları ve önerileri) nedir?

\section{YÖNTEM}

Çalışma nitel araştırma desenlerinden durum çalışması biçiminde desenlenmiştir. Durum çalışması sınırlı bir sistemin derinlemesine betimlenmesi ve incelenmesi, güncel bir olgunun gerçek bağlamında ele alınmasıdır (Merriam, 2013). "Nitel durum çalışmasının en temel özelliği bir ya da birkaç durumun derinliğine araştırılmasıdır" (Yıldırım ve Şimşek, 2011: 77). Bu çalışmada, fen bilimleri öğretiminde bilimsel öyküleme yöntemi üzerine yapılan bilimsel yayınlar belirlenen ölçütlere göre incelenip durum tespiti yapılmak istendiği için çalışma durum çalışması yaklaşımıyla araştırma yapılandırılmıştır.

\section{a) Veri Kaynağı ve Veri Toplama Aracı}

Yayınları tanımlamak için veri tabanları aşağıdaki anahtar kelimeler kullanılarak taranmıştır: "bilimsel öykü" veya "bilimsel hikâye" veya "fende hikâyelendirme" veya "fende öyküleme" ve "bilim insanı" veya "öykü" veya "hikâye" ve "fen öğretimi". Veritabanlarından Tablo 2'deki matrise göre toplam 29 yayın alınmıştır. Bu yayınlar referans bölümünde "*" ile işaretlenmiştir (örneğin, * Coşkun, 2012). Ülkemizde 2005-2019 yılları yayınlanan eğitim dergileri, Yüksek Öğretim Kurumu [YÖK] tez veri tabanı ve TÜBİTAK ULAKBİM veri tabanı taranarak yayınlara ulaşılmıştır. 
Tablo2. Yayın siniflama matrisi

\begin{tabular}{|c|c|c|}
\hline Temalar & Kodlar & Açıklamalar \\
\hline \multirow{3}{*}{ Genel özellikleri } & Yayın yılı & Yayınlanan çalışma yılı \\
\hline & Yazar sayısı & Çalışmadaki yazar sayısı \\
\hline & Yayın türü & Yayın grubu (makaleler, kongre, tez vb.) \\
\hline \multirow{6}{*}{ İçerik Özellikleri } & Amaçları & Çalışmanın amacı \\
\hline & Yöntemler & $\begin{array}{l}\text { Nitel (vaka çalışması, fenomenoloji vb.) Nicel (anket, } \\
\text { deneysel vb.) }\end{array}$ \\
\hline & Veri toplama araçları & $\begin{array}{l}\text { Verilerin elde edilmesinde kullanılan araçlar } \\
\text { (gözlem, görüşme, Likert ölçeği, vb.) }\end{array}$ \\
\hline & Hikâye türleri & $\begin{array}{l}\text { Verilerin elde edilmesinde kullanılan bilimsel } \\
\text { öyküler (Bilimsel kahramanlık öyküleri, Bilimsel } \\
\text { keşif öyküleri, Tanıtıcı bilim öyküleri, Politik açıdan } \\
\text { doğrulayıcı bilim öyküleri) }\end{array}$ \\
\hline & Sonuçlar & Çalışmanın temel sonuçları \\
\hline & Öneriler & $\begin{array}{l}\text { Araştırmacıların sonuçlarından yola çıkarak } \\
\text { eğitimcilere, araştırmacılara, uygulama ortamlarına } \\
\text { vb., yönelik önerileri }\end{array}$ \\
\hline
\end{tabular}

\section{b) Veri Analizi}

$\mathrm{Bu}$ araştırmada fen bilimleri öğretiminde bilimsel öyküleme yöntemi üzerine yapılan çalışmalar içerik analizi yoluyla incelenmiştir. İçerik analizi sözel, yazılı ve diğer veri kaynaklarının tematik bir şekilde incelenmesini sağlayan bilimsel bir yaklaşımdır (Tavşancıl ve Aslan, 2001). Her çalışma matris kullanılarak ayrı ayrı incelenmiş̧ir ve çalışmalardaki genel eğilimler Tablo 2'de verilen kod ve temalara göre belirlenmiştir. İçerik analizi yaklaşımlarından betimsel içerik analizi tercih edilmiştir. Betimsel içerik analizi, farklı kişilerin aynı soru hakkındaki düşüncelerinden elde edilen verilerin daha önceden belirlenen başlık altında ve temalar çerçevesinde kategorize edilerek özetlenmesi ve yorumlanmasıdır (Altunışık, Coşkun, Yıldırım ve Bayraktaroğlu, 2010).

Veri tabanlarından ulaşılan çalışmaları analiz etmek için yukarıdaki matris kullanılmıştır. İlk olarak, her kategoriye karşılık gelen kodlar hazırlanmıştır. Örneğin, her bir çalışma yayınlandığı yıl, yayın türü ve yazar sayısına göre kategorize edilmiştir. Ardından, çalışmaların amaçları kodlanmıştır. Ortak hedeflere sahip çalışmalar aynı kod altında gruplandırılmıştır. Benzer genel amaçlı çalışmalarla, kodlar birleştirilerek tema adı altında adlandırılmıştır. Diğer kod ve temaların oluşturulmasında da benzer süreçler izlenmiştir.

\section{c) Çalışmanın Sınırlandırılması}

$\mathrm{Bu}$ araştırma fen bilimleri öğretiminde bilimsel öyküleme yöntemi ile ilgili yapılan çalışmalar ve bu konuyla ilgili veri tabanları kullanılarak sunulan makaleler, tezler ve konferans yazıları gibi yayınlarla sınırlandırılmıştır. Araştırma etiği için kodlama süreci, araştırma yazarlarından başka bir araştırmacı tarafından denetlenmiştir. Çalışma önyargıları bu şekilde azaltmayı hedeflemiştir. 


\section{d) Çalışmanın Güvenilirliği}

$\mathrm{Bu}$ çalışmada kullanılan veri toplama aracı olan ölçeğin birçok araştırmada kullanılması güvenilebilir araç olduğunu göstermektedir (B1kmaz, Aksoy, Tatar ve Altınyüzük, 2013; Yücel-Toy, 2015; Deveci ve Çepni, 2017). Ayrıca ölçeğin güvenirliğini arttırmak için de araştırmacının yarattığ1 kodlar ve temalar diğer araştırmacıların oluşturdukları ile karşılaştırılabilir. Araştırmacı yazar tarafından bu çalışma için yeniden oluşturulmuş ölçekteki kodlar ve temalar fen bilimleri öğretiminde uzman olan farklı bir araştırmacının yaptığı kodlama ile karşılaştırılmış ve uyuşma katsayısı 0.87 bulunmuştur. Sonra tartışma sonucunda anlaşmaya varılan kodlar ve temalar ölçekte kullanılmıştır.

\section{BULGULAR}

$\mathrm{Bu}$ bölüm, incelenmekte olan çalışmaların genel özellikleri ve içerik özellikleri hakkında bulgular içermektedir.

Başlangıç olarak elde edilen çalışmaların yayın yılı, yazar sayısı ve yayın türü olarak genel özellikleri incelenmiştir. Tablo 3'te çalışmaların genel özellikleriyle ilgili bulgular sunulmuştur.

Tablo 3. Çalışmalar hakkında genel bilgi

\begin{tabular}{llc}
\hline Temalar & Kodlar & $\mathrm{f}$ \\
\hline \multirow{3}{*}{ Yayın yılı } & $2005-2009$ & 5 \\
& $2010-2014$ & 11 \\
& $2015-2019$ & 13 \\
\hline \multirow{3}{*}{ Yazar sayısı } & Tek & 17 \\
& İki & 7 \\
& Üç yazar & 5 \\
\hline \multirow{3}{*}{ Yayın türü } & Dört yazar ve üstü & - \\
& Doktora tezi & 3 \\
& Yüksek lisans tezi & 12 \\
& Makale & 12 \\
\hline
\end{tabular}

Tablo-3 incelendiğinde yirmi dokuz çalışma 2015-2019 yılları arasında (13), 2010-2014 yıllarında (11) ve 2005-2009 yılları arasında (5) yapılmıştır. Yazar sayısı açısından bakıldığında çalışmaların büyük bir kısmının tek yazarlı (17), geri kalanın ise iki yazarlı (7) ve üç yazarlıdır (5). Çalışmaların yayın türü ise yüksek lisans tezi (12) ve makale (11) olarak yazılmış olup sempozyum (1) ve doktora (3) da tercih edilen diğer türler olmuştur.

Tablo 4'de yapılan çalışmaların neyi amaçladığı incelenmiş, bu doğrultuda temalar oluşturulmuş ve dağılımları gösterilmiştir. 
Tablo 4. Çalışmaların amaçlarına göre dağılımı

\begin{tabular}{|c|c|c|c|}
\hline Temalar & Kodlar & $\mathrm{f}$ & $\begin{array}{l}\text { Genel } \\
\text { toplam }\end{array}$ \\
\hline \multirow{14}{*}{$\begin{array}{l}\text { Akademik } \\
\text { başarı, tutum, } \\
\text { motivasyon, } \\
\text { özyeterlik, } \\
\text { bilimsel } \\
\text { süreç } \\
\text { becerileri, } \\
\text { bilginin } \\
\text { kalıcılığı }\end{array}$} & $\begin{array}{l}\text { Öyküleme ve deney tekniğinin, ilkokul öğrencilerinin başarısına ve kavram } \\
\text { öğrenmesine olan etkisinin incelenmesi. }\end{array}$ & \multirow{14}{*}{14} & \multirow{14}{*}{29} \\
\hline & $\begin{array}{l}\text { Bilimsel öykülerle fen bilimleri derslerinin desteklenmesinin fene yönelik } \\
\text { tutuma, bilim insanı imajına, bilimsel süreç becerilerine ve akademik } \\
\text { başarıya etkisinin incelenmesi. }\end{array}$ & & \\
\hline & $\begin{array}{l}\text { Fen ve Teknoloji öğretiminde bilimsel öyküler içeren eğitsel oyunların, } \\
\text { öğrencilerin akademik başarılarına etkisinin incelenmesi. }\end{array}$ & & \\
\hline & $\begin{array}{l}\text { Fen ve Teknoloji öğretiminde bilim öyküleri içeren eğitsel oyunların, } \\
\text { öğrencilerin akademik bașarılarına etkisinin incelenmesi. }\end{array}$ & & \\
\hline & $\begin{array}{l}\text { Kavram karikatürleriyle desteklenmiş bilimsel hikâyelerin kullanımının } \\
\text { öğrencilerin akademik başarıları, tutumları ve motivasyonları üzerine } \\
\text { etkisinin belirlenmesi. }\end{array}$ & & \\
\hline & $\begin{array}{l}\text { Öykü yönteminin çocukların alıcı ve ifade edici dil ile bilimsel sözcük } \\
\text { kazanımlarına etkisinin incelenmesi. }\end{array}$ & & \\
\hline & $\begin{array}{l}\text { Kavramların öğretiminde hikâyelendirme tekniğinin öğrencilerin } \\
\text { başarılarına ve tutumlarına olan etkisinin incelenmesi. }\end{array}$ & & \\
\hline & $\begin{array}{l}\text { Bilim öyküleri içeren öyküleme yönteminin, öğrencilerin akademik } \\
\text { basarılarına ve derse iliskin tutumlarına etkisinin incelenmesi. }\end{array}$ & & \\
\hline & $\begin{array}{l}\text { Popüler bilim kitaplarının öğretim materyali olarak kullanılmasının, } \\
\text { öğrencilerin akademik başarılarına, bilgilerinin kalıcılığına ve fene yönelik } \\
\text { tutumlarına etkisinin incelenmesi. }\end{array}$ & & \\
\hline & $\begin{array}{l}\text { Kavram karikatürleriyle desteklenmiş bilimsel hikâyelerin önemli öğrenme } \\
\text { ürünlerinden olan akademik başarı, tutum ve motivasyon üzerine etkisinin } \\
\text { incelenmesi. }\end{array}$ & & \\
\hline & $\begin{array}{l}\text { Bilişim teknolojileri destekli kısa hikâyelerin öğrencilerin Fen ve Teknoloji } \\
\text { dersindeki başarılarına, öz yeterlik algılarına ve fene yönelik tutumlarına } \\
\text { etkisinin incelenmesi. }\end{array}$ & & \\
\hline & $\begin{array}{l}\text { Bilimsel hikâyelerle desteklenen fen bilimleri öğretiminin ortaokul } \\
\text { ögrencilerinin yaratıcılık ve derse karşı geliştirdikleri duyuşsal özelliklere } \\
\text { olan etkilerinin incelenmesi. }\end{array}$ & & \\
\hline & $\begin{array}{l}\text { Yaratıcı dramada alt bir teknik olan öyküleme çalışmalarının fen bilimleri } \\
\text { öğretiminde kullanımına ilişkin görüşlerinin alınması. }\end{array}$ & & \\
\hline & $\begin{array}{l}\text { Fen bilgisi ögretmen adaylarının bilimsel hikâyelerin kullanımına yönelik } \\
\text { görüşlerinin belirlenmesi. }\end{array}$ & & \\
\hline \multirow{7}{*}{$\begin{array}{l}\text { Bilim insanı } \\
\text { imajı }\end{array}$} & $\begin{array}{l}\text { Bilimsel öykülerin kullanımının öğrencilerin fen bilimleri dersine karşı } \\
\text { tutumlarına ve bilim insanı imajlarına etkisi }\end{array}$ & \multirow{7}{*}{7} & \multirow{7}{*}{29} \\
\hline & $\begin{array}{l}\text { Bilim insanlarının yaşam hikâyelerinden kesitler sunmanın öğrencilerin } \\
\text { biyoloji dersine yönelik tutumlarına etkisini incelenmesi. }\end{array}$ & & \\
\hline & $\begin{array}{l}\text { Fen Bilimleri ders kitaplarının, bu kitaplarda sunulan bilim insanlarının } \\
\text { cinsiyet, milliyet (kültür), dış görünüm, çalışma ortamı ve yaşam öyküsü } \\
\text { verilip verilmemesi yönlerinden incelenmesi. }\end{array}$ & & \\
\hline & Bilim insanlarının hayatının ele alınması. & & \\
\hline & $\begin{array}{l}\text { Bilim insanlarının çocukluk dönemi yaşantılarındaki ve bilimsel kariyer } \\
\text { süreçlerindeki benzer yaşantıların belirlenmesidir. }\end{array}$ & & \\
\hline & $\begin{array}{l}\text { İlkokul öğrencilerinin bilim insanı imajlarının belirlenmesi ve bu imajların } \\
\text { oluşmasında ders kitaplarının ve]öğretmenlerin rolünün tespit edilmesi. }\end{array}$ & & \\
\hline & $\begin{array}{l}\text { Ülkemizdeki bilim insanlarının çocukluk yaşantıları ile bilimsel kariyer } \\
\text { süreçlerindeki ortak noktalarını derinlemesine incelemek. }\end{array}$ & & \\
\hline \multirow{3}{*}{$\begin{array}{l}\text { Kitap-Metin } \\
\text { inceleme }\end{array}$} & $\begin{array}{l}\text { Kitabın oluşum aşamalarının görsel öğeler kullanılarak sunulması ve alana } \\
\text { katkısının değerlendirilmesi. }\end{array}$ & \multirow{3}{*}{3} & \multirow{3}{*}{29} \\
\hline & $\begin{array}{l}\text { Bilimsel kavramları öğrenmede kullanılan yazılı metin çeşitlerinin kısaca } \\
\text { incelenmesi ve "hikâyelendirme tekniği”. }\end{array}$ & & \\
\hline & $\begin{array}{l}\text { Hikâyelere dayalı öğretim programının amaçlan, açıklayıcı hikâyeler ve } \\
\text { kimyasal hikâyelerin öğrenme onamında kullanımının incelenmesi. }\end{array}$ & & \\
\hline
\end{tabular}




\begin{tabular}{|c|c|c|c|}
\hline \multirow{3}{*}{$\begin{array}{l}\text { Kavram } \\
\text { ögretimi }\end{array}$} & $\begin{array}{l}\text { Kavram karikatürleriyle desteklenmiş bilimsel hikâyeler temel alınarak bir } \\
\text { rehber materyalin geliştirilmesi }\end{array}$ & \multirow{3}{*}{3} & \multirow{3}{*}{29} \\
\hline & $\begin{array}{l}\text { Kavramları öğrenmede hikâyelendirme tekniğinin etkisinin ne düzeyde } \\
\text { olduğunun ortaya çıkarılması. }\end{array}$ & & \\
\hline & $\begin{array}{l}\text { Öğrencilerin ‘Tansiyon' kavramını anlamalarında hikâye anlatım } \\
\text { yönteminin etkililiğinin incelenmesi. }\end{array}$ & & \\
\hline \multirow[b]{2}{*}{$\begin{array}{l}\text { Bilimin } \\
\text { doğas1 }\end{array}$} & $\begin{array}{l}\text { Fen bilgisi öğretmen adaylarının bilimin doğası hakkındaki görüşlerini } \\
\text { değerlendirmek için kısa hikâye yönteminin etkililiğinin incelenmesi. }\end{array}$ & \multirow[b]{2}{*}{2} & \multirow[b]{2}{*}{29} \\
\hline & $\begin{array}{l}\text { Fen bilgisi öğretmen adaylarının bilimin doğası hakkındaki görüşlerinin } \\
\text { ölçek ve kısa hikâyeler yoluyla tespit edilmesi ve kısa hikâyelerin ölçme } \\
\text { değerlendirme aracı olarak öğretim ortamında kullanılması. }\end{array}$ & & \\
\hline
\end{tabular}

Tablo 4'te görüldüğü gibi çalışmaların amaçları incelendiğinde, yapılan çalışmaların bilimsel öyküleme yönteminin akademik başarı, tutum, motivasyon, öz yeterlik, bilimsel süreç becerileri ve bilgilerin kalıcılığına etkisini incelemeyi amaçladığı görülmektedir (13). Öğrencilerin bilim insanı imajına vurgu yapılmıştır (7). Bu amaçlara ek olarak, kavram öğretimine yönelik çalışmalar yapılmıştır (3); fen bilimleri öğretim programlarının kazanımlar ve ders kitabı etkinlikleri açısından incelenmesini amaçlayan çalışmalar yapılmaktadır (3). Ayrıca bilimin doğası hakkındaki görüşleri ve bilimsel öyküleme yönteminin bu konuda etkililiğini belirlemeyi amaçlayan çalışmalar da yapılmıştır (2).

Tablo 5' de, çalışmaların tercih edilen yaklaşım ve bu yaklaşımların başlıkları altındaki yöntemlere göre dağılımı incelenmiştir.

Tablo 5. Çalışmaların tercih edilen yöntemlere göre dağılımı

\begin{tabular}{llcc}
\hline Araştırma yaklaşımı & Yöntemler & f & Genel toplam \\
\hline Nicel araştırma & Deneysel araştırma & 12 & 12 \\
\hline \multirow{4}{*}{ Nitel araştırma } & Fenomenoloji araştırma & 3 & \\
& Doküman inceleme & 1 & 7 \\
& Durum çalışması & 2 & \\
& Sadece nitel araştırmaların yapıldı̆̆ını belirtti & 1 & \\
\hline Karma araştırma & Sadece karma araştırmaların yapıldığını belirtti & 5 & 5 \\
\hline \multirow{2}{*}{ Diğer } & Teorik araştırma & 1 & 1 \\
& Belirtilmemiş & 4 & 4 \\
\hline
\end{tabular}

Tablo 5 incelendiğinde, nicel yaklaşım başlığı altında deneysel araştırma yöntemlerinin kullanıldığ görülmüştür (12). Ayrıca nitel yaklaşımla hazırlanan çalışmalarda ise fenomenolojik araştırma yöntemi (3), doküman inceleme (1) ve durum çalışması (2) yöntemlerinin kullanıldığı tespit edilmiştir. Bazı araştırmacılar basitçe 'karma yöntem' (5) kullandıklarını açıklamışlardır. Ek olarak, bir araştırma teorik olarak gerçekleştirilmiştir. Diğer araştırmalarda ise çalışma yöntemi hakkında bir açıklama olmadığı görülmüştür (4).

Tablo 6'de yapılan çalışmalarda araştırmanın amacına uygun olarak kullanılan veri toplama araçlarına göre dağılımı incelenmiştir. 
Tablo 6. Çalışmaların tercih edilen veri toplama araçlarına göre dağılımı

\begin{tabular}{lc}
\hline Veri Toplama Araçları & f \\
\hline Başarı testleri & 17 \\
Tutum ölçekleri & 12 \\
Motivasyon ölçeği & 2 \\
Formlar & 11 \\
Mantıksal Düşünme Yetenek Testi & 1 \\
DAST (Draw A Scientist Test-Bir Bilim İnsanı Çiz Testi) & 3 \\
Mülakat & 1 \\
Öz yeterlik ölçekleri & 1 \\
Anket & 2 \\
Öykü günlükleri & 1 \\
Ders kitapları & 1 \\
Torrance Yaratıcı Düşünme Testi Şekilsel Kısım & 1 \\
Bilimsel süreç becerileri testi & 1 \\
Kısa Hikâyeler & 2 \\
Bilimsel Bilginin Doğası Ölçeği & 1 \\
Türkçe İfade Edici ve Alıcı Dil Testi (TİFALDİ) & 1 \\
Belirtilmemiş & 6 \\
\hline
\end{tabular}

Tablo 6'da görüldüğü gibi, araştırmacılar çalışmalarının amaçlarına uygun veri elde etmek için başarı testlerini (17), tutum ölçeklerini (12) görüşme, gözlem ve tanıma formlarını (11) tercih etmişlerdir. Ayrıca, araştırmacıların yetenek (1), beceri (1), düşünme (1) ve dil(1) testlerinden, kısa hikâyeler(2) ve öykü günlükleri (1), anket(2), mülakattan (1) faydalandığı da görülmüştür.

Tablo 7'de araştırmacıların yaptıkları çalışmalardaki tercih ettikleri veri toplama araçlarının sayısına göre dağılımı gösterilmiştir.

Tablo 7. Çalışmalarda tercih edilen veri toplama araçlarının sayıya göre dağılımı

\begin{tabular}{lll}
\hline Bir çalışmada tercih edilen veri toplama aracı sayısı & f & Genel Toplam \\
\hline Veri toplama aracı sayısı 1 olanlar & 8 & \multirow{2}{*}{29} \\
Veri toplama aracı sayısı 2 ve daha fazla olanlar & 21 & \\
\hline
\end{tabular}

Tablo 7'de görüldüğü gibi, yapılan araştırmalarda birden fazla tek bir tane veri toplama aracı kullanılmıştır (21). Ayrıca araştırmacıların tek veri toplama aracıyla çalışmalarını tamamladıkları görülmüştür (8).

Tablo 8'de araştırmacıların yaptıkları çalışmalardaki tercih ettikleri bilimsel öykülerin konularına göre türlerinin dağglımı gösterilmiştir.

Tablo 8. Çalışmaların tercih edilen bilimsel öykülerin konusuna göre dağılımı

\begin{tabular}{llc}
\hline Konularına göre hikâye türleri & f & Genel Toplam \\
\hline Bilimsel kahramanlık öyküleri & 4 & \\
Bilimsel keşif öyküleri & 5 & 23 \\
Tanıtııı bilim öyküleri & 14 & \\
Politik açıdan doğrulayıcı bilim öyküleri & - & \\
\hline
\end{tabular}


Tablo 8'de görüldüğg̈ gibi, araştırmalar çalışmalarında tanıtıcı bilim öykülerini kullanmışlardır (14). Bunun yanı sıra bilimsel keşif öyküleri (5) ve bilimsel kahramanlık öykülerini (4) tercih eden araştırmacılar vardır. Fakat politik açıdan doğrulayıcı bilim öykülerini konu edinen çalışmaya rastlanmamıştır.

Tablo 9'de araştırmacıların yaptıkları çalışmalardaki tercih ettikleri katılımcı gruplar ve grupların seviyelerinin dağılımı incelenmiştir.

Tablo 9. Çalışmaların tercih edilen örneklem gruplarına göre dağılımı

\begin{tabular}{|c|c|c|c|}
\hline Katılımcılar & Örnek Seviyesi & f & $\begin{array}{l}\text { Genel } \\
\text { Toplam }\end{array}$ \\
\hline \multirow{4}{*}{ Eğitimci/ Öğretmen } & İlkokul & 1 & \multirow{4}{*}{2} \\
\hline & Ortaokul & 0 & \\
\hline & Lise & 0 & \\
\hline & Üniversite (akademik öğretim görevlisi) & 1 & \\
\hline \multirow{5}{*}{ Öğrenci } & Okul öncesi & 1 & \multirow{5}{*}{24} \\
\hline & İlkokul & 5 & \\
\hline & Ortaokul & 13 & \\
\hline & Lise & 1 & \\
\hline & Üniversite (öğretmen adayları) & 4 & \\
\hline Belirtilmemiș & & 3 & 3 \\
\hline
\end{tabular}

Tablo 9'daki tercih edilen örneklem gruplara bakıldığında, bazı araştırmaların üniversite düzeyinde çalışan eğitimcileri tercih ettiği görülmüştür (1). Diğer araştırmaların okul öncesi (1), ilkokullarda (5), ortaokullarda (13) eğitim alan öğrencileri, liselerde (1) eğitim alan öğrencileri ve üniversitede eğitim alan öğretmenleri (4) tercih ettiği görülmüştür. Diğer taraftan, çalışmaların geri kalanında örneklemeyle ilgili herhangi bir ifade olmadığı tespit edilmiştir (3).

Tablo 10' da yapılan araştırmalar elde edilen sonuçlarına göre temalar altında toplanmış ve incelenmiştir.

Tablo 10. Çalışmaların elde edilen sonuçlara göre dağılımı

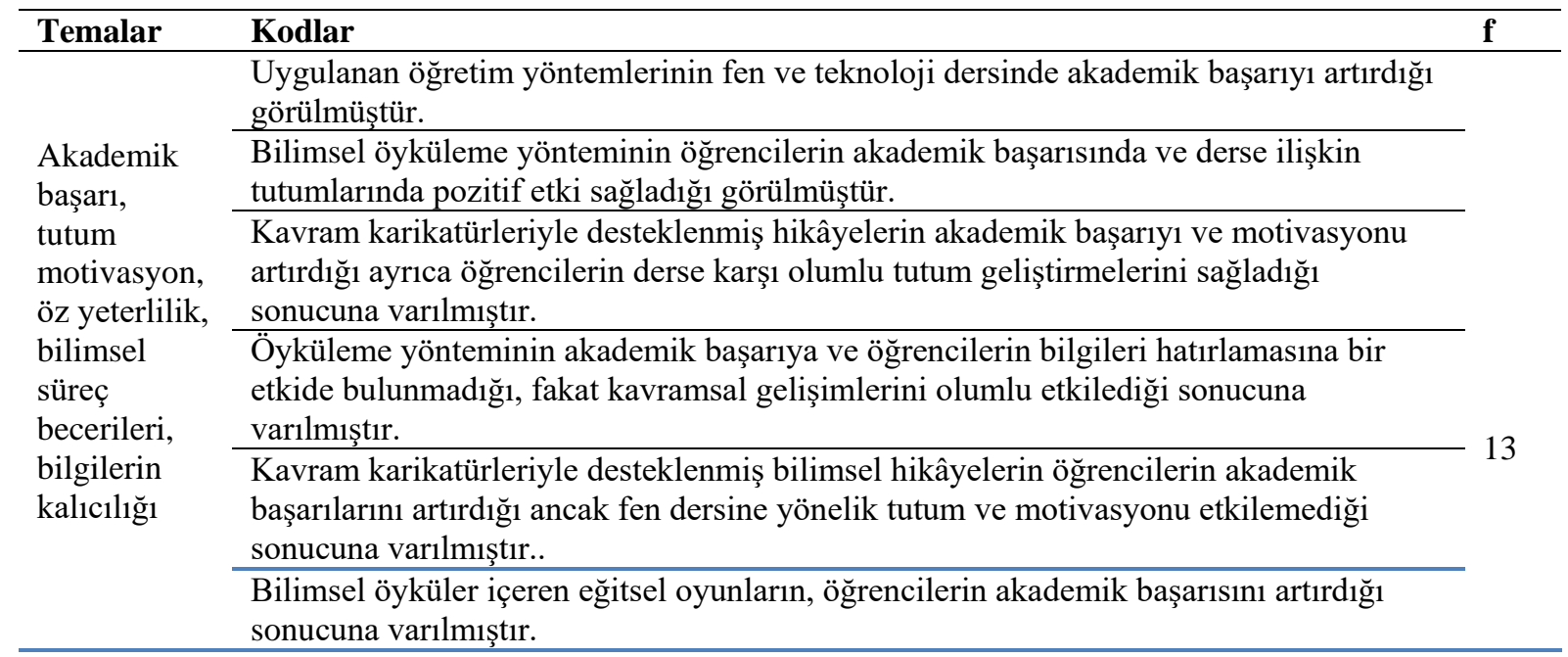




\begin{tabular}{|c|c|c|}
\hline & $\begin{array}{l}\text { Bilimsel öykülerle desteklenen fen derslerinin öğrencilerin akademik başarısını } \\
\text { arttırdığı, fene karşı olumlu tutum geliştirmelerini sağladığı, bilimsel süreç } \\
\text { becerilerinin gelişmesini desteklediği ve bilim insanı imajlarını olumlu yönde } \\
\text { değiștirdiği sonucuna varılmıștır. }\end{array}$ & \\
\hline & $\begin{array}{l}\text { Hikâyelendirme tekniğinin akademik başarı üzerinde etkili olduğu sonucuna } \\
\text { ulaşılmıştı. }\end{array}$ & \\
\hline & $\begin{array}{l}\text { Fen dersi kapsamında popüler bilim kitaplarının öğretim materyali olarak } \\
\text { kullanılmasının öğrencilerin akademik başarısını ve bilgilerinin kalıcılığını artırdığı ve } \\
\text { fenne yönelik tutum üzerinde olumlu etkiye sahip olduğu ortaya konulmuştur. }\end{array}$ & \\
\hline & $\begin{array}{l}\text { Bilimsel hikâyeler kullanmanın öğrenci tutumlarını etkilemediği ancak öğrencileri } \\
\text { rahatlattığı ve dersi daha eğlenceli hale getirdiği belirlenmiştir. }\end{array}$ & \\
\hline & $\begin{array}{l}\text { Bilişim teknolojileri destekli kısa hikâyelerle öğrencilerin akademik başarılarının } \\
\text { arttğ̆ı, derse yönelik daha olumlu tutum geliştirdikleri ve fene karşı öz yeterlik } \\
\text { algılarının yükseldiği belirlenmiştir. }\end{array}$ & \\
\hline & $\begin{array}{l}\text { Uygulanan öğretim yöntemlerinin fen ve teknoloji dersine yönelik öğrenci tutumlarını } \\
\text { etkilemediği sonucuna ulaşıllmıştır. }\end{array}$ & \\
\hline & $\begin{array}{l}\text { Bilimsel hikâyelerle desteklenen fen öğretiminin öğrencilerin yaratıcılık ve fene } \\
\text { yönelik tutumlarında belirgin bir farklılık oluşturmadığı sonucuna ulaşılmıştır. }\end{array}$ & \\
\hline \multirow{6}{*}{$\begin{array}{l}\text { Bilim insanı } \\
\text { imaj1 }\end{array}$} & $\begin{array}{l}\text { Öykü haritaları ile desteklenmiş bilimsel öyküler sayesinde öğrencilerin doğada gözlem } \\
\text { yapan, canlılar üzerinde çalışan, gözlüksüz bilim insanı çizdikleri görülmüștür. }\end{array}$ & \\
\hline & $\begin{array}{l}\text { Kitaplardaki bilim insanlarının sayıca orantısız olduğu ve çoğunluğunun Avrupa } \\
\text { kökenli, erkek, orta çağ ve eski yunandaki kalıplaşmış bilim insanı figürleri olduğu } \\
\text { görülmüştür. }\end{array}$ & \\
\hline & $\begin{array}{l}\text { Bilim tarihindeki örnekler göstermektedir ki, bilim insanı bir toplumda ortaya } \\
\text { çımakta, o toplumun önünden giderek toplumu geliştirmekte, evrensel kültüre katkılar } \\
\text { sağlamaktadır. }\end{array}$ & \\
\hline & $\begin{array}{l}\text { Bilim insanı olma ve kariyere yönlenmenin çoğunlukla üniversite yıllarında belirgin } \\
\text { hale geldiği sonucuna ulaşılmıştır. }\end{array}$ & \\
\hline & $\begin{array}{l}\text { Bilim insanlarının çocukluk yaşantılarında ve bilimsel kariyer süreçlerindeki tecrübe } \\
\text { birikimlerinde ortak yaşantılar olduğu ortaya çıkmıştır. }\end{array}$ & \\
\hline & $\begin{array}{l}\text { Öğrencilerin, daha önce yapılan çalışmalarda olduğu gibi bilim insanına yönelik } \\
\text { basmakalıp imajlara sahip olduğu belirlenmiş̧tir. Ayrıca öğrencilerin sahip olduğu bilim } \\
\text { insanı imajlarını etkileyen en temel faktörlerin öğretmenler ve ders kitapları olduğu } \\
\text { tespit edilmiştir. }\end{array}$ & \\
\hline \multirow{6}{*}{$\begin{array}{l}\text { Öğretme- } \\
\text { Öğrenme } \\
\text { yaklaşımı }\end{array}$} & $\begin{array}{l}\text { Yaratıcı drama ve özel olarak öyküleme çalışması ile öğrenme anlamlı ve daha } \\
\text { zevklidir. }\end{array}$ & \multirow{6}{*}{6} \\
\hline & $\begin{array}{l}\text { Öykü yönteminin 48-72 aylık çocukların alıcı-ifade edici dil sözcük bilgilerini ve } \\
\text { bilimsel sözcük kazanımlarını etkilediği sonucuna ulaşıılmıştır }\end{array}$ & \\
\hline & $\begin{array}{l}\text { Hikâyeleştirme yönteminin fen yararlı bir yöntem olduğu ve kavramların anlaşılmasına } \\
\text { katkı sağladığı sonucuna varılmıştır. }\end{array}$ & \\
\hline & $\begin{array}{l}\text { Bilimsel metinlerin sergileyici ve tartışmacı öğrenme etnikleriyle bilimsel bilgiler ders } \\
\text { kitaplarımızda veya ilgili kaynaklarda verilmiştir. }\end{array}$ & \\
\hline & $\begin{array}{l}\text { Kimyasal hikâyelerin öğrencilerin öğrenmeye karşı istekliliklerini artırdığı ve anlamlı } \\
\text { öğrenmeyi gerçekleştirdiği söylenebilir. }\end{array}$ & \\
\hline & $\begin{array}{l}\text { Öğretmen adaylarının bilimsel hikâyelere yönelik olumlu düşüncelerinin olduğu } \\
\text { belirlenmiştir. }\end{array}$ & \\
\hline $\begin{array}{l}\text { Rehber } \\
\text { materyal } \\
\text { geliştirme }\end{array}$ & $\begin{array}{l}\text { Fen ve teknoloji derslerinde kavram karikatürleriyle desteklenmiş bilimsel hikâyeleri } \\
\text { içeren bir rehber materyale yer verilmiştir. }\end{array}$ & 1 \\
\hline $\begin{array}{l}\text { Kitap } \\
\text { inceleme }\end{array}$ & $\begin{array}{l}\text { "Tombul Çekirdek ve Anadolu Yer Sincabı-Gelengi kitabında, erken çocukluk } \\
\text { dönemindeki çocukların kazanması beklenen kavramlara yer verilerek onların bilim } \\
\text { dünyası ile sıcak bir ilişki kurmalarına çalışılmıştır. }\end{array}$ & 1 \\
\hline \multirow{2}{*}{$\begin{array}{l}\text { Bilimin } \\
\text { Doğas1 }\end{array}$} & $\begin{array}{l}\text { Analizler sonucunda katılımcıların bilimin doğası görüşlerinin birbirinden farklı } \\
\text { oldukları görülmüştür. }\end{array}$ & 1 \\
\hline & $\begin{array}{l}\text { Kısa hikâyelerin bilimin doğası hakkındaki görüşleri saptamada bir yöntem olarak } \\
\text { kullanılabileceği yapılan analizlerle ortaya konulmuştur. }\end{array}$ & 1 \\
\hline
\end{tabular}


Tablo 10'da, araştırmalardan elde edilen sonuçlarda akademik başarı, tutum, motivasyon, öz yeterlilik, bilimsel süreç becerileri ve bilgilerin kalıcılığının yüksek olduğu görülmektedir (13). Ayrıca, bilim insanı imajı ile ilgili sonuçlara ulaşılmıştır (6). Öğretme-öğrenme süreci ile ilgili sonuçlara da ulaşıldığı görülmektedir (6). Öğretim faaliyetleri ögesi olan ders kitapları da incelenmiş ve sonucunda ders içi materyal de geliştirilmiştir (2). Ayrıca bilimin doğasıyla ilgili yapılan çalışmalarda kısa öykülerin etkisine dair sonuçlara ulaşılmıştır (2).

Tablo 11 yapılan çalışmalar sonucunda araştırmacıların sunduğu önerilerin temalar altında dağılımını göstermektedir.

Tablo 11. Çalışmaların önerilere göre dağılımı

\begin{tabular}{|c|c|c|}
\hline Temalar & Kodlar & \\
\hline \multirow{5}{*}{$\begin{array}{l}\text { Eğitimci- } \\
\text { öneriler }\end{array}$} & $\begin{array}{l}\text { Lisans dönemindeki öğretmen adaylarına, branş derslerine yönelik hikâyeler } \\
\text { yazdırılabilir. }\end{array}$ & \multirow{5}{*}{5} \\
\hline & $\begin{array}{l}\text { Bilim insanlarının yaşam öykülerinde sadece bilimsel çalışmalara değil sosyal } \\
\text { ilişkilere, sportif faaliyetlere, gezip-eğlenme gibi günlük yaşamla ilgili örneklere yer } \\
\text { verilerek "'Bilim insanları sadece ve sürekli bilimsel çalışmalarla uğraşır" algısı } \\
\text { değiştirilebilir. }\end{array}$ & \\
\hline & $\begin{array}{l}\text { Öğretmen adaylarının bilimin doğası hakkındaki görüşlerini değiştirmek ve } \\
\text { geliştirmek üzere yeni araştırmalar ve uygulamalar yapılmalıdır. Özellikle öğretmen } \\
\text { adaylarının bu konuda sahip oldukları kavram yanılgılarının kaynağı hakkında detaylı } \\
\text { araştırmalar yapılmalıdır. }\end{array}$ & \\
\hline & $\begin{array}{l}\text { Üniversite eğitim fakültesinde öğrenim gören öğrencilere bilimsel hikâye oluşturma } \\
\text { konusunda eğitim verilmeli, bilimsel hikâye hazırlama ve hazırlatma becerileri } \\
\text { kazanmaları sağlanmalıdır. }\end{array}$ & \\
\hline & $\begin{array}{l}\text { Kadın bilim insanlarının yaşam öyküleri anlatılıp "bilim adamı" kavram algısını } \\
\text { ortadan kaldırmaya yönelik faaliyetler yapılabilir. }\end{array}$ & \\
\hline \multirow{9}{*}{$\begin{array}{l}\text { Araştırmacıl } \\
\text { ar için } \\
\text { öneriler }\end{array}$} & $\begin{array}{l}\text { İlköğretim öğrencilerine yönelik bilimsel hikâyelerin kullanıldığı deneysel çalışmalar } \\
\text { tasarlanabilir.. }\end{array}$ & \multirow{9}{*}{9} \\
\hline & $\begin{array}{l}\text { Piyasadaki popüler bilim kitaplarının öğretim programının hedeflerini hangi ölçüde } \\
\text { karşıladığını belirlemeye yönelik çalışmalar yapılabilir. }\end{array}$ & \\
\hline & $\begin{array}{l}\text { "Bilimsel İçerikli Öykülerle Desteklenen Eğitim Programı’nın etkisi yaş, bilişsel } \\
\text { gelişim, anne-baba öğrenim düzeyi, sosyo-ekonomik düzey, okul öncesi eğitim } \\
\text { kurumlarına devam etme durumu gibi farklı değişkenler açısından araştırılabilir. }\end{array}$ & \\
\hline & $\begin{array}{l}\text { Sonuçların değişimi hakkında bilgi edinebilmek için daha uzun bir sürede } \\
\text { uygulamaların gerçekleştirilmesi önerisinde bulunulabilir. }\end{array}$ & \\
\hline & $\begin{array}{l}\text { Fen bilgisi öğretmen adaylarının bilimin doğası hakkındaki görüşlerinden sadece } \\
\text { gelişimsellik, test edilebilirlik, yaratıcılık boyutları değerlendirilmiş̧tir. Daha sonra bu } \\
\text { amaçla yapılacak araştırmalarda bilimin doğasının farklı boyutlarını da içeren kısa } \\
\text { hikâyeler kullanılmalıdır. }\end{array}$ & \\
\hline & $\begin{array}{l}\text { Benzer çalışmalarda bilim insanlarının yaşam öyküleriyle desteklenen derslerin } \\
\text { bilimsel yaratıcılık düzeyine etkisi araştırılabilir. }\end{array}$ & \\
\hline & $\begin{array}{l}\text { Bilimsel hikayelerin öğrencilerin başarı, motivasyon, tutum gibi değişkenler üzerinde } \\
\text { etkileri araștırılabilir. }\end{array}$ & \\
\hline & Sosyal Bilgiler veya Türkçe öğretmen adaylarının görüşleri araştırılabilir. & \\
\hline & $\begin{array}{l}\text { Başka bir çalışmada farklı yayınevlerinin hazırladığı ve daha farklı seviyelerdeki fen } \\
\text { kitapları ve hatta farklı disiplinlerin ders kitaplarındaki bilim insanlarının imajları } \\
\text { açısından incelenebilir. }\end{array}$ & \\
\hline
\end{tabular}




\begin{tabular}{|c|c|c|}
\hline \multirow{15}{*}{$\begin{array}{l}\text { Yaklaşım, } \\
\text { strateji, } \\
\text { yöntem, } \\
\text { teknik ve } \\
\text { öğrenme } \\
\text { ortamları } \\
\text { için öneriler }\end{array}$} & $\begin{array}{l}\text { Uygulaması kolay ve öğretim ilkelerine uygun seçilecek öyküler, öğrencilerin başarılarına } \\
\text { olumlu katkı sağlayacaktır. }\end{array}$ & \\
\hline & $\begin{array}{l}\text { Öğrencilerin fen bilimleri derslerini mümkün olduğunca somut materyallerle, yaparak ve } \\
\text { yaşayarak islenmesi gerekmektedir. }\end{array}$ & \\
\hline & $\begin{array}{l}\text { İlköğretimde keyifli ve eğlenceli süreçler içeren, yaratıcıllı̆ğ geliştiren, öğrenmelerde } \\
\text { kalıc1lı̆̆ sağlayan, soyut kavramları somutlaştıran aktif öğrenci merkezli drama yöntemi } \\
\text { daha çok benimsenmelidir. }\end{array}$ & \\
\hline & $\begin{array}{l}\text { Elde edilen sonuçların fen öğretiminde popüler bilim kitapları, popüler bilim dergileri, } \\
\text { gazeteler vb. farklı bilgi kaynaklarının kullanımı ve bu doğrultuda ders kitaplarının } \\
\text { şekillenmesi konusunda yol gösterici olabileceği düşünülmektedir. }\end{array}$ & \\
\hline & $\begin{array}{l}\text { Yarı yapılandırılmış görü̈şme yöntemiyle bilim insanlarının çocukluk yaşantılarını ve } \\
\text { bilimsel kariyer sürecini daha net verilerle ortaya amaçlayan çalışmaların yapılması önemli } \\
\text { görülmektedir. }\end{array}$ & \\
\hline & $\begin{array}{l}\text { Hikâyeler özgün, dikkat çekici ve öğrencilerin eğitim kademelerine uygun bir şekilde } \\
\text { oluşturulmasına özen gösterilmelidir. }\end{array}$ & \\
\hline & $\begin{array}{l}\text { Özellikle birinci kademede fen bilgisi derslerine gerekli özen gösterilmeli ve laboratuvar } \\
\text { etkinliklerine mümkün olduğunca yer verilmelidir. }\end{array}$ & \\
\hline & $\begin{array}{l}\text { Bilimsel hikâyelerin kavram haritaları gibi farklı alternatif yöntem ve tekniklerle } \\
\text { desteklenerek akademik başarı, tutum ve motivasyon üzerine etkisinin araştırılması } \\
\text { önerisinde bulunulabilir. }\end{array}$ & 5 \\
\hline & $\begin{array}{l}\text { Hikâyelendirme tekniğinin uygulanmasında sadece hazır hikâyeler kullanılmayarak } \\
\text { öğrencilerin de bilimsel hikâyeler oluşturmalarına firsat verilebilir. }\end{array}$ & \\
\hline & $\begin{array}{l}\text { Fen ve teknoloji dersinin diğer ünitelerinde ve konularında bilişim teknolojileri destekli } \\
\text { kısa hikâyeler yöntemi ile ilgili çalışmalar yapılabilir. }\end{array}$ & \\
\hline & $\begin{array}{l}\text { Bilim insanlarının yaşam öykülerine bilimsel yöntem basamaklarını çağrıştıran ifadeler } \\
\text { yerleştirilerek sınıf ortamında öğrencilere bu basamaklar bulundurulabilir ve sınıf } \\
\text { ortamında tartışıbilir. }\end{array}$ & \\
\hline & $\begin{array}{l}\text { Bilimsel bilginin öğrencilere gerek soru-cevap, gerekse tartışma teknikleriyle ulaşmasına } \\
\text { yardımcı olacak hikâyelendirme tekniği faydalı olacaktır. }\end{array}$ & \\
\hline & $\begin{array}{l}\text { Uygulaması kolay ve öğretim ilkelerine uygun seçilecek öyküler, öğrencilerin başarılarına } \\
\text { olumlu katkı sağlayacaktır. }\end{array}$ & \\
\hline & $\begin{array}{l}\text { Hikâyelendirme tekniğinin, diğer aktif öğrenme teknikleriyle birlikte kullanılarak etkisi } \\
\text { artırılabilir. }\end{array}$ & \\
\hline & $\begin{array}{l}\text { Hikâyelendirme tekniğinin öğrenci sayısı az olan sınıflarda uygulanması daha iyi sonuçlar } \\
\text { oluşturabilir. }\end{array}$ & \\
\hline \multirow{4}{*}{$\begin{array}{l}\text { Müfredat } \\
\text { için öneriler }\end{array}$} & $\begin{array}{l}\text { Özellikle Fen Bilimleri dersinde akılda kalması zor olan bilimsel kavramlar tespit edilerek } \\
\text { ilköğretim müfredatında bulunan kazanımlar doğrultusunda gerek akademisyenler gerekse } \\
\text { branș öğretmenleri tarafından hikayeler oluşturulabilir. }\end{array}$ & \\
\hline & $\begin{array}{l}\text { Kavram karikatürleri ve bilimsel hikâyelere fen ve teknoloji öğretim programlarında yer } \\
\text { verilmesi önerisinde bulunulabilir. }\end{array}$ & 4 \\
\hline & $\begin{array}{l}\text { Öğretim programları yalnızca öğrenme etkinliklerini içermemeli, aynı zamanda öğrenme } \\
\text { adımlarını da içermeli ve geleceğin fen öğretim programları daha fazla çeşitliliğe sahip } \\
\text { olmalıdır. }\end{array}$ & \\
\hline & Fen ve Teknoloji dersi farklı seviye ve konularına da araştırmalar yapılabilir. & \\
\hline \multirow{5}{*}{$\begin{array}{l}\text { Uygulamalı } \\
\text { çalışmalar } \\
\text { için öneriler }\end{array}$} & $\begin{array}{l}\text { Hikâyelendirme tekniği ile kavramların öğretimine daha fazla önem verilmesi, uygulama } \\
\text { çalışmalarının Milli Eğitim Bakanlığı tarafindan desteklenmesi gerekmektedir. }\end{array}$ & \\
\hline & $\begin{array}{l}\text { Öğretmenlerin kavramları öğrencilerine nasıl aktarabilecekleri konusunda bilgi ve beceri } \\
\text { yönünden eğitilmeleri gerekmektedir. }\end{array}$ & \\
\hline & Farklı derslerde yapılacak uygulamalar ile mevcut uygulama karşılaştırılabilir. & \\
\hline & $\begin{array}{l}\text { Hikâyelendirme tekniği kullanımı yaygınlaştırma ve etkin kullanma amaçlı olarak } \\
\text { öğretmenlere hikâyelendirme tekniği hakkında hizmet içi eğitim kursları verilebilir. }\end{array}$ & \\
\hline & $\begin{array}{l}\text { Okul öncesi eğitim kurumlarında “Bilimsel İçerikli Öykülerle Desteklenen Eğitim } \\
\text { Programı” ve materyallerinin kullanımına ilişkin eğitim seminerleri düzenlenerek } \\
\text { öğretmenlerin kullanımına sunulabilir. }\end{array}$ & \\
\hline \multirow{3}{*}{$\begin{array}{l}\text { Aileler için } \\
\text { öneriler }\end{array}$} & $\begin{array}{l}\text { Öğrencilerin yaratıcılıklarını öldürülmemeli ve öğrenciler yaratıcılıklarını } \\
\text { kullanabilecekleri alanlara yönlendirilmelidirler. }\end{array}$ & \\
\hline & $\begin{array}{l}\text { Hem bilimsel kariyere yönelmede hem de bu süreçte başarılı olmada, bireylere çocukluk } \\
\text { dönemlerinde özgür olacakları yaşantıların sunulacağı ortamların hazırlanması } \\
\text { önerilmektedir. }\end{array}$ & 2 \\
\hline & Belirtilmemiş & 1 \\
\hline
\end{tabular}


Tablo 11'de görüldüğü gibi araştırmacılar, yaklaşım, strateji, yöntem, teknik ve öğrenme ortamları için önerilerde bulunmuştur (15). Alanda çalışacak olan araştırmacılar (9), eğitimciler (5), uygulamalı çalışmalar için önerilerle devam etmektedir (5). Fen dersi öğretim programını kapsayan müfredat için (4) öneri bulunmaktadır. Diğer yandan aileler için öneride bulunan araştırmacılar da $\operatorname{vardır}(2)$.

\section{TARTIŞMA VE SONUÇ}

Bu bölümde yapılan analizlerde elde edilen bulgulardan yola çıkılarak ulaşılan sonuçlar literatür destekli başlıklar altında tartışılmış ve yorumlanmıştır.

\section{a) Genel özellikler}

Bilimsel öyküler öğrencilerin ön bilgilerini harekete geçirip yeni bilgileri yapılandırırken zihinlerinde oluşan kavram yanılgılarını düzeltir, bilime yönelik ilgilerini artırır ve bilim insanı imajlarını değiştirir (Driver, Asoko, Leach,, Mortimer \& Scott, 1994). Diğer deyişle bilimsel öyküler bireyin fen okuryazarı olması yönünde önemli katkılar sağlar. Bu bağlamda bilimsel öykü ile ilgili yapılan çalışmalar incelediğinde ise son yıllarda yapılan çalışmalarda bilimsel öyküleme yöntemine eğilimin arttığı görülmektedir; bu da bilimsel öyküleme yöntemine ilginin arttığını göstermektedir. $\mathrm{Bu}$ durumun ortaya çıkmasında 2013 ve 2018 Fen Bilgisi Dersi Öğretim Programı’nın bireyleri fen okuryazar birey olarak yetiştirmesi üzerine inşa edilmesi önemli bir neden olarak gösterilebilir (MEB, 2018). Bu yönelimin son yıllarda artmasında ikinci bir sebep olarak da çocuklara yönelik bilim alanında yayınlanan dergi ve kitap tür ve sayılarının artması gösterilebilir (Demircan, 2016). Diğer taraftan bilim çocuk kitap ve dergilerinde bulunan uygulama çalışmaları ve metinler öğrencilerin bilim alanında gelişimlerine katkı sağlarken, okul veya okul dışı öğrenme ortamlarını öğrenciler için eğlenceli hale getirmektedir (Selim, 2013). Bu gibi gelişmeler bilimsel düşünmeyi amaçlayan fende, bilimsel öyküleme yönteminin kullanılması anlamında eğilime yol açmış olabilir.

Ayrıca ulusal literatürde yer alan çalışmalar incelediğinde yazar sayısına göre çalışmaların bir veya iki kişi şeklinde az sayıda yazarlı olduğu görülmüştür (Bertiz, 2005; Y1lmaz, 2013; Okyay, 2015; Ünver, 2015; Bayram, 2018; Zengin ve Küçük, 2018). Bu bulgular ülkemizde yapılan farklı içerik analizi çalışmaların sonuçlarıyla (Alper \& Gülbahar, 2009; Tatar, Kağızmanlı ve Akkaya, 2014; Kutluca ve Demirkol, 2016; Kutluca, Birgin ve Gündüz, 2018) benzerlik göstermektedir. Bu durumun birinci nedeni olarak, araştırmacıların ekip çalışmasına yeterince yatkın olmamaları veya araştırmacılar arasındaki işbirliğinin zayıflığı gösterilebilir (Alper ve Gülbahar, 2009). İkinci neden olarak ise akademik ürünler değerlendirilirken yazar sayısı arttıkça alınan puan azaldığından, araştırmacıların az yazarlı çalışmalara ağırlık vermek zorunda kaldıkları söylenebilir (Kutluca, Birgin ve Gündüz, 2018). Bunun yanı sıra doçent adaylarının lisansüstü öğrencileriyle birlikte hazırladıkları çalışmaların da tek yazarlı olarak kabul edilmesi iki ya da daha fazla sayıda yazarlı makalelerin daha az sayıda olmasında üçüncü bir neden olarak kabul edilebilir (Akaydın ve Çeçen, 2015). Bilimsel 
öyküleme yöntemi eğitimde yeni bir araştırma alanı olarak düşünüldüğünden, bu alanda proje ya da ortak çalışmanın bulunamamasının çok da çarpıcı bir durum olmadığı söylenebilir. Deveci ve Çepni’ye göre (2016) yayınlar ancak projelerden veya ortak araştırmalardan çıktığında, birden çok yazara sahip olabilir. Bu bağlamda bilimsel öykü temelli bir proje ortaya koyulabilmesi için birden fazla disipline ait uzmanlık gerektiren (Fen, Türkçe, Matematik, Görsel Sanatlar vb.) disiplinlerarası bir yaklaşımın benimsenmesi gerekir. $\mathrm{Bu}$ sonuçlar doğrultusunda bilimsel öyküleme yönteminin, disiplinlerarası bir niteliği olan Fen Bilimleri ve diğer derslerin öğretim programına dâhil edilmesiyle birlikte ilerleyen zamanlarda birden çok yazarlı çalışmaların yayınlandığını görmek mümkün olabilir.

Son olarak, araştırmacıların çalışmalarını çoğunlukla yüksek lisans tezi olarak hazırladığı görülmüştür (Dincel, 2005; Coşkun, 2012; Yılmaz, 2013; Çınar, 2016; Gölcük, 2017). Bunun nedeni olarak son yıllarda lisansüstü eğitime olan talepteki artış gösterilebilir (Bıkmaz vd., 2013). Bu durum Türkiye'de eğitim alanında, öğretmenlerin kendilerini geliştirmek amacıyla yüksek lisans yapmalarıyla açıklanabilir (Yavuz ve Yavuz, 2017). Ayrıca tezlerden çalışma üretildiği düşünüldüğünde bilimsel öykü alanında çok sayıda makalenin olması şaşırtıcı bir durum değildir. $\mathrm{Bu}$ sonuç İslamoğlu, Ursavaş ve Reisoğlu'nun (2015) araştırma bulgularıla benzerlik göstermektedir. Buna bağlı olarak son yıllarda öğretim programlarındaki değişim ve gelişimin fen bilimleri alanında araştırmacılara yeni konularda çalışma imkânı sunduğu düşünülebilir.

Fakat alanında orijinal bir çalışma olan doktora tezi çalışmalarına çok az sayıda yer verilmiştir (Polat, 2011; Okyay, 2015; Kılıç, 2019). Yavuz ve Yavuz (2017) yaptığı 2002-2014 yılları arasında fen bilimleri öğretiminde yapılan proje tabanlı öğretimle ilgili tezlerin içerik analizi çalışmasında da benzer sonucu bulmuştur. Araştırmacı bu durumu eğitimcilerin yüksek lisans programı sonrasında doktora eğitimine akademik olarak devam etmeyi tercihen sürdürmeleriyle açıklamıştır. Bu bağlamda bilimsel öykü alanında orijinal çalışmaların sayısının artması için doktora araştırmalarına yüksek lisans öğrencilerinin teşvik edilmesi gerekmektedir.

\section{b) Amaçlar}

Yapılan çalışmalar amaçlarına göre analiz edildiğinde ise çok fazla sayıda araştırmacının bilimsel öyküleme yönteminin akademik başarı, tutum, motivasyon, öz yeterlilik, bilimsel süreç becerileri ve bilginin kalıcılığına etkisini incelenmeyi amaçladığı görülmektedir (Dincel, 2005; Coşkun, 2012; Yılmaz, 2013; Kuş, 2014; Pekmezci, 2014; Tolgay, 2018). Bu durumun nedeni araştırmacıların fen bilimleri öğretiminde bilimsel öyküleme yönteminin uygulama boyutuna odaklanması olarak düşünülebilir. Bu bağlamda bilimsel öykülemenin fen bilimleri öğretimine nasıl entegre edildiğinin literatürde bir merak konusu olduğu düşünülebilir. Araştırmacılara göre bilimsel öyküler fen öğretiminde hedeflenen amaçlara ulaşması için öğrencilere motive edici ve eğlenceli bir öğrenme ortamı oluşturur, öğrencilerin düşünme stratejilerini güçlendirir ve öğrenme becerileri için stratejiler geliştirmelerini sağlar (McLellan, 2006; Gómez, 2010). Bu durumda fen bilimleri 
öğretiminin kapsamına alınan bilimsel öyküleme yönteminin de birçok hedefi yerine getireceği düşünülebilir.

Ayrıca bu çalışmada çok sayıda araştırmacının öğrencilerin bilim insanı imajını ortaya çıkarmayı amaçladıkları görülmüştür (Güler ve Akman, 2006; Bağ, 2013; Yar, 2017; Zengin, 2018). Bunun nedeni olarak, bilimsel öykülerin çocukları bilim dünyası ile tanıştırmak ve keşfedenlerin yalnızca beyaz önlük giymiş bireyler olduğu düşüncesini değiştirmek için tasarlanmış metinler olması gösterilebilir (Ebbers, 2002). Diğer bir neden ise yenilenen fen bilimleri öğretim programımın öğrencilerin bilim, teknoloji, mühendislik ve matematik alanlarında kariyer bilinci ve becerilerini geliştirmeyi amaçlaması gösterebilir (MEB, 2018). Bu bağlamda fende bilimsel öyküleme yöntemiyle sunulan metinler aracığıyla bilim insanı imajına dair yeni fikirlerin önünün açılacağg düşünülebilir.

Bunlara ek olarak az sayıda araştırmacının bilimsel öyküleme yöntemi ile kavram öğretimini amaçladıkları görülmüştür (Türkmen ve Ünver, 2012; Ören ve Yılmaz, 2013; Akgül, Geçikli ve Doğan, 2017). Bilimsel öyküleme yönteminin öğrencilerin konular hakkındaki ön bilgilerini harekete geçirip yeni bilgileri yapılandırırken zihinlerinde oluşan kavram yanılgılarını da düzeltme imkânı sağlayan bir yöntem olduğu düşünüldüğünde bu durumun oldukça dikkat çekici bir durum olduğu söylenebilir. Özellikle var olan kavram öğretimi çalışmalarının tanıtıcı bilim öyküleri kullanılarak yapıldığ1 tespit edilmiştir. Diğer taraftan fende kavramlar bilimsel kahramanlık öyküleri ve bilimsel keşif öykülerinde verilerek bilimsel öyküleme yöntemiyle kavramların öğretimi yeni araştırmalara konu edilebilir.

\section{c) Yöntemler}

Yapılan çalışmalar yaklaşım ve yöntemleri açısından analiz edildiğinde araştırmacıların büyük bir çoğunluğunun nicel araştırma yaklaşımı benimsedikleri ve bu yaklaşım altında deneysel çalışmalar yaptıkları görülmektedir (Şen-Gümüş, 2009; Coşkun, 2012; Köklükaya ve Yıldırım, 2015; Akgül vd., 2017; Tolgay, 2018). Bu durumun nedeni nitel araştırmaların çok zaman alması ve derinlemesine bir araştırma gerektirmesi, verilerinin toplanması ve çözümlenmesinin uzun uğraşlar gerektirmesi olarak düşünülebilir (Akaydın ve Çeçen, 2015). Deneysel çalışmaların daha çok yürütülme sebebi ise araştırmacıların çalışma grubundan elde ettik verileri kullanılarak durumlar arası neden sonuç ilişkisi kurmak istemleri gösterilebilir (Balcı, 2015). Bu bağlamda yukarıda bahsedildiği gibi araştırmacıların çoğunluğu tarafından bilimsel öyküleme yönteminin sınıflarda öğretmenler tarafindan uygulanmasının arzulandığı düşünülebilir. Ayrıca nitel yaklaşım benimsenerek yapılan çalışmalarda ağırlıklı olarak fenomonolojik yöntemin kullanıldığı görülmektedir. Fenomenolojik araştırma yönteminin kullanılması, araştırmacıların öğrenme ortamı ögelerinin bilimsel öyküleme yöntemine dair tecrübelerine ilişkin algılarını belirlemek istemesiyle örtüşebilir.

Bununla birlikte bu çalışmada nitel ve nicel yaklaşımın birlikte kullanılarak araştırma problemine cevap arandığı bir araştırma yöntemi olan karma yönteminin de az sayıda araştırmacı 
tarafindan tercih edildiği görülmüştür. Bu yöntemin ulusal alan yazında son yıllarda yeni kullanılmaya başlanması ve araştırmacıların bu yöntem ile yeni tanışmış olmasından dolayı karma araştırma yöntemine dair yeterli bilgi ve beceriye sahip olmamaları gösterilebilir (Lee, Wu ve Tsai, 2009; Chang, Chang ve Tseng, 2010). Bu durumda bilimsel öyküleme yöntemi ve fen bilimleri öğretiminin disiplinlerarası bir içeriğe sahip olmasının araştırmacıların karma yaklaşım benimsemelerine olanak sağladığı düşünülebilir.

\section{d) Veri toplama araçları}

Yapılan çalışmalarda araştırmacıların ne tür veri toplama aracı kullandığı incelediğinde ise başarı testleri, tutum, motivasyon ölçeklerini ağırlıklı olarak tercih ettiği belirlenmiştir. Görüşme, mülakat, gözlem ve araştırmacı günlüklerinin ise araştırmalarda daha az kullanıldığı görülmektedir. Bu bulgular eğitim alanında yapılan içerik analizi çalışmalarıyla benzerlik göstermektedir (Selçuk, Z., Palanc1, M., Kandemir, M. ve Dündar, H., 2014; İslamoğlu, Ursavaş ve Reisoğlu, 2015). Özellikle testlerin fazla kullanılmasının nedeni bu araçların geniş bir alandan veri elde etmesi, elde edilen verilerin SPSS gibi uygun programlar kullanılarak kolayca hesaplanabilmesi gösterilebilir (Zorluoğlu ve Elbir, 2019). Bu durum, araştırmaların büyük çoğunluğunda nicel yöntem ve deneysel desenin kullanılmasıyla paralellik göstermektedir ve bu veri toplama araçlarının kolay ulaşılabilir, kolay yorumlanabilir ve ekonomik olması tercih edilme sebebi olabilir. Diğer taraftan daha çok nitel araştırma yöntemlerinde tercih edilen bilim insanı çizimleri, mülakat, öykü günlükleri ve kısa hikâyeler gibi veri toplama araçlarının çok fazla tercih edilememe sebebi ise bu araçlardan elde edilen verilerin betimsel analiz yöntemiyle uzun süren ve yorucu bir süreç sonucunda bulguya dönüşmesidir.

Diğer taraftan incelenen araştırmalarda veri toplamak için birden fazla veri toplama aracının kullanıldığ1 görülmüştür (Akgül, Geçikli, Doğan, 2017; Korkut ve Ören, 2018; Tolgay, 2018) Bu durumun ortaya çıkma nedeni araştırmada elde edilen verilerinin geçerliliğini arttırmaktadır. Çünkü bir araştırmada bulgular farklı veri toplama araçlarıyla desteklendiğinde, araştırma verilerinin geçerliliği artacaktır (Fraenkel, Wallen ve Hyun, 2012; akt. Saraç ve Kunt, 2016). Bu durumda akademik başarı, motivasyon, tutum, bilginin kalıcıllğı vb. testleri gibi sık kullanılan veri toplama araçlarının yanında gözlem ve görüşme formu, mülakat, günlük gibi daha az kullanılan veri toplama araçlarının kullanımına ağılık verilmesi, daha nitelikli araştırmaların ortaya çıkmasına katkı sağlayabilir.

\section{e) Hikâye türleri}

Araştırmacıların çalışmalarında kullandıkları bilimsel öykülerinin büyük bir çoğunluğunun tanıtıcı bilim öyküleri türü olduğu görülmüştür (Dincel, 2005; Şen-Gümüş, 2009; Cındı1, Özmen ve Ünal, 2012; Kuş, 2014; Gölcük, 2017). Bu durumun nedeni olarak tanıtıcı bilim öyküleriyle kavramların somut bir şekilde öğretilmesi ve öğrenilen bilgilerin doğada gözlemlenebilmesi gösterilebilir (Milne, 1998). Özellikle çalışmalarda bilimin doğası konularının ağırlıklı olarak tercih 
edilmesi de bir neden olarak düşünülebilir. Diğer taraftan bilimsel keşif öykülerinin de oldukça tercih edildiği görülmüştür (Bertiz, 2005; Polat, 2011; Pekmezci, 2014; Çınar, 2016). Bu öykü türünün uygulandığı sınıflarda öğrencilerin günlük hayattaki olaylara ve problemlere bilimsel yaklaşarak analitik düşünceyle çözüm üretmenleri bir fen okur-yazarı bireyden beklenen davranış olması bu durumu açıklayabilir. Diğer taraftan araştırmacılar diğer öykü türlerine göre bilimsel kahramanlık öykülerinin daha az tercih etmişlerdir (Karaçam, Aydın ve Digilli, 2014; Unat,2017). Bu durum az sayıda bilim insanı imajı ile ilgili çalışmaların yapılması ile örtüşmektedir. Bu öykülerde öğrencilerin bilim insanları imajını belirlemek, değiştirmek ve geliştirmek için bilimsel kahramanlık öyküleri tercih edilerek öğrencilerin kendilerini kahramanın yerine koymaları istenmektedir (Milne, 1998). Bu çalışmada elde edilen dikkat çekici bir durumu ise politik açıdan doğrulayıcı bilim öykülerini araştırmacıların konu olarak tercih etmemesidir. Bunu nedeni öğretim programı kapsamında konularda bilime sosyo politik açıdan yaklaşılmıyor olması olarak düşünülebilir. Bu bağlamda fen programının bu boyutu ele alınıp politik açıdan doğrulayıcı bilimsel öyküler hazırlanabilir ve böylece insanların günlük yaşamdaki olayları inanç ve kültür farklılıklarına göre nasıl yorumladıkları tespit edilebilir ve yanılgılar bu açıdan ele alınarak düzeltilebilir.

\section{f) Çalışma grubu}

Araştırmacıların çalışmalarındaki çalışma grupları inceldiğinde ise en çok ortaokullarda eğitim alan öğrenciler ve üniversite öğrencilerinin tercih edildiği görülmüştür (Dincel, 2005; Köklükaya ve Yıldırım, 2015; Akgül vd., 2017; Gölcük, 2017). Bu sonuç Saracaloğlu ve diğerlerinin (2014) araştırma bulgularıyla benzerdir. $\mathrm{Bu}$ durum tercih edilen örneklemlerin öğrenme ortamının temel ögelerinden olan öğrenciler olması ile açıklanabilir. Ortaokul öğrencilerin en çok seçilme nedeni olarak araştırmacıların ögrencilerin erken yaşlarda bilim insanlarıyla ortak yaşantıya sahip olma fırsatını elde etmesi gösterilebilir. Diğer taraftan üniversite öğrencileri ile çalışılmasının nedeni olarak araştırmacıların çalıştı̆̆ kurumlarda örneklemin tamamen mevcut olması, ulaşması hızlı ve kolay olması ve maliyetin az olması gösterebilir. Özellikle hikâye sayesinde birçok kazanımın öğrencilere kazandırıldığı okul öncesinde bilimsel öyküleme yönteminin çok az sayıda kullanılmasının sebebi olarak bu alandaki öğrencilerin okuma yazma bilmemesi ve veri elde etmek için uygun bir veri toplama aracının literatürde olmaması gösterilebilir. Fakat özellikle bilim insanı imajının okul öncesi dönemde oluşmaya başladığı düşünüldüğünde bu dönemde bilimsel öykü yöntemi çalışmalarının yapılması oldukça önemlidir. Ayrıca öğretim programlarını uygulayan öğretmen adaylarının bilimsel öykü yönteminin önemini ve sınıflarda kullanma şeklini anlamaları da diğer önemli bir noktadır.

\section{g) Sonuçlar}

Yapılan araştırmalardan elde edilen sonuçlara bakıldığında fen bilgisi öğretiminde bilimsel öyküleme yönteminin kullanılması öğrencilerin akademik başarı, tutum ve motivasyonu arttırdığı görülmektedir (Pekmezci, 2014; Çınar, 2016; Korkut ve Ören, 2018; Tolgay, 2018). Bilimin meraktan 
doğduğu hatırlandığında burada bilimsel öyküleme yönteminin öğrencilerin başarılarını etkileyen tutum ve motivasyon duygularını harekete geçirmede etkili olduğu düşünülebilir (Pekmezci, 2014). Öte yandan bilimsel öyküleme yönteminin öğrencilerin öz yeterlilik, bilgilerin kalıcıllğı ve bilimsel süreç becerileri gibi becerileri geliştirdiği saptanmıştır. $\mathrm{Bu}$ becerileri geliştirmesi özellikle bu yöntemin fen okuryazarı birey yetiştirmede önemli bir yöntem olduğunu göstermektedir (MEB, 2018). Ayrıca öyküleme çalışması ile öğrenmenin anlamlı ve daha zevkli hale geldiğine dair sonuçlara da rastlanmaktadır. Çalışmalardan elde edilen bir başka sonuç ise öyküleme yönteminin bilim insanı imajlarının değiştirdiği ve geliştirdiğidir (Korkmaz ve Kavak, 2010; Cındıl, Özmen ve Ünal, 2012; Coşkun, Akarsu ve Kariper, 2012; Dönmez, 2017; Zengin ve Küçük, 2018). Öğrencilerin sahip olduğu bilim insanı imajının gelecekteki kariyer seçiminde önemli bir faktör olduğu düşünüldüğünde bu gibi çalışmaların sayısının artmasının gelecekte ülkemizin bilim insanı sayısının artmasında faydalar sağlayacağ 1 düşünülmektedir.

Öğretim programları bağlamında araştırma sonuçları incelediğinde ise bilimsel öykü yönteminin fen bilimleri ders kitaplarının içeriğinde yeteri kadar hatta hiç yer tespit edilmiştir. Bu eksikliği gidermeye yönelik olarak ise rehber materyal olarak sınıflarda öğretmenler ve eğitimciler tarafindan kullanılabilecek örnek çalışmaların yapıldığı belirlenmiştir (Ören ve Yılmaz, 2013; Karaçam, Aydın ve Digilli, 2014). Bu bağlamda rehber materyal geliştirme çalışmaları öğretmenlerin de kendi sınıflarında bu tür etkinlikleri yapması bakımından önemlidir. Diğer taraftan bu yöntemin sınıflarda uygulanmasının artmasının fen okuryazar birey sayısının artmasında önemli bir etken olacağı düşünülmektedir. Bu sonuçların fen bilimleri öğretimi için çok önemli olduğu söylenebilir. Fen bilimleri öğretiminde bilimsel öyküleme yönteminin eksikliklerini belirleyen eylem planları hazırlamak mümkündür.

\section{h) Öneriler}

Araştırmacıların çalışmalarında eğitimcilere ve diğer araştırmacılara yönelik olarak yaptığ öneriler incelediğinde önerilerin çoğunlukla bilimsel öyküleme yönteminin sınıflarda öğrenme ve öğretme yaklaşımı, strateji, yöntem ve teknik olarak kullanımı ile ilgili olduğu belirlenmiştir (Dincel, 2005; Köklükaya ve Yıldırım, 2005; Şen-Gümüş, 2009; Coşkun, 2012; Kuş, 2014; Çınar, 2016; Akgül, Geçikli ve Doğan, 2017; Korkut ve Ören, 2018). Örnek olarak; “'Hikâyelendirme tekniğinin uygulanmasında sadece hazır hikâyeler kullanılmayarak öğrencilerin de bilimsel hikâyeler oluşturmalarına fırsat verilebilir'” önerisi gösterilebilir. Bu sonuçları destekleyici olarak Ünver (2015) özellikle ilköğretim öğrencilerinin dinlemekten ve okumaktan hoşlandıkları hikâye, masal, öykü gibi metin türlerine bilimsel bilgiyi katarak öğrenmelerinin daha kalıcı olacağına ifade etmektedir. Diğer taraftan bilimsel öykülemenin sınıflarda çeşitli şekillerde uygulanması problem çözme, analitik düşünme, yaratıcı düşünme, eleştirel düşünme, gibi bir fen okuryazar bireye ait birtakım becerilerin kazandırılma sürecini kaliteli hale getirebilir. 
Ayrıca incelenen çalışmalarda diğer bir öneri ise bilimsel dergilerde, gazetelerde, internette yer alan bilimsel metinlerin de fen bilimleri öğretimine entegre edilmesi yönündedir. Günümüz dünyasında internetin çok yaygın olmasının, bilim adamlarının yaşam öykülerinin yer almasının ve sınıflarda FATİH projesiyle sınıflarda akıllı tahtanın bir öğrenme aracı olarak bulunmasının bu önerinin uygulanabilirliğini arttığı söylenebilir.

Bunlara ek olarak çok az sayıda araştırmacı çalışmasında ailelere önerilerde bulunmuştur. Gür ve Haktanır'a göre (2007) günlük yaşamdaki olaylar karşısında bilimsel düşünmeyi alışkanlık haline getirmek ailelerin çocuklarına sağlayacağı çeşitli imkânlar ile mümkündür. Ailelerin çocuklarına bilimsel düşünme becerisini kazandırabilmelerinin en kolay yolu ise onların küçük yaşta bilim kitaplarıyla tanışmalarını ve sevmelerini sağlamaktır.

Sonuç olarak fen bilimleri öğretiminde bilimsel öyküleme yönteminin kullanımı üzerine yapılan çalışmaların sayısında son yıllarda artış olması dikkat çekicidir. Ayrıca, çalışmaların hedeflerinin çoğu bilimsel öyküleme yöntemiyle ilgili başarı, ilgi, tutum, motivasyon, öz yeterlilik, bilginin kalıcılığı ve bilimsel süreç becerilerini tespit etmektir. Diğer taraftan incelenen çalışmalarda nicel yaklaşım yöntemlerinden deneysel yöntemin ve nitel yaklaşım yöntemlerinden fenomenolojik araştırma yönteminin çoğu çalışmada tercih edildiği görülmüştür. Ayrıca yapılan çalışmalarda araştırmacılar veri toplama araçları olarak Likert tipi ölçekleri kullanmışlardır. İncelenen çalışmalarda örneklem grupları olarak çoğu çalışma ortaokul öğrencilerini tercih etmiş, bunu ilkokul öğrencileri ve öğretmen adaylarının takip etmiştir. İncelenen çalışmalarda çok sayıda araştırma sonuçlarının bilimsel öyküleme yönteminin öğrencilerin akademik başarısı, tutumu, motivasyonu, öz yeterlilikleri, bilimsel süreç becerileri ve öğrenilen bilgilerin kalıcılığını arttırdığına yönelik olduğu görülmüştür. Ayrıca incelenen araştırmalarda önerilerin çoğu fen bilgisi öğretiminde bilimsel öykü yönteminin kullanımı için sunulmuştur. Yapılan çalışmalarda daha çok alanda çalışacak olan araştırmacılar ve sınıf ortamında bilimsel öyküleme yönteminin uygulayıcısı eğitimciler için de önerilerde bulunulmuştur.

Fen bilimleri öğretiminde bilimsel öyküleme yönteminin kullanılması üzerine çalışmalar yürütülmesi konusunda aşağıdaki öneriler yapılabilir:

Gelecekteki çalışmalarda nitel yaklaşım ve karma yaklaşım yöntemleri tercih edilerek mülakat, gözlem, çizim, günlük, grup görüşmesi veya bunlara ek olarak nicel veri toplama araçları da kullanılarak araştırmaların niteliği arttırılabilir.

Örneklem grupları açısından, ilkokul öğrencileri ve öğretmenleri üzerinde yapılan çalışma sayısının arttırılabileceği söylenebilir.

Gelecekteki araştırmalarda, okul öncesi öğretim programında da fen bilimleri öğretiminde bilimsel öyküleme yöntemi ile ilgili çalışmalar yapılabilir. 


\section{KAYNAKÇA}

Altunışık, R., Çoşkun, R., Yıldırım, E., \& Bayraktaroğlu, S. (2010). Sosyal bilimlerde araştırma yöntemleri.6. Bask1, Sakarya: Sakarya Kitapevi.

Akaydın, Ş., \& Çeçen, M.A. (2015). Okuma Becerisiyle ilgili makaleler üzerine bir içerik analizi. Eğitim ve Bilim Dergisi, 40(178), 183-198.

Akgül, G. D., Geçikli, E., \& Doğan L. (2017). Fen eğitiminde hikâyelendirme tekniği ile kavram öğretimine bir aksiyon örneği. Uluslararası Ĕ̆itim Bilimleri Dergisi, 4(11), 246-274.

Alper, A., \& Gülbahar, Y. (2009). Trends and issues in educational technologies: A review of recent research in TOJET. The Turkish Online Journal of Educational Technology - TOJET, 8(2), 124-135.

Arık, R. S., \& Türkmen, M. (2009). Eğitim bilimleri alanında yayımlanan bilimsel dergilerde yer alan makalelerin incelenmesi. I. Uluslararası Türkiye Eğitim Araştırmaları Kongresi'nde sunulan bildiri, Çanakkale.

Azizoğlu, N., \& Çetin, G. (2009). 6. ve 7. sınıf öğrencilerinin öğrenme stilleri, fen dersine yönelik tutumları ve motivasyonları arasındaki ilişki. Kastamonu Eğitim Dergisi, 17(1), 171-182.

Bağ, H. (2013). 4 ve 5. sinıf öğrencilerinin bilim insanı imajları. Recep Tayyip Erdoğan Üniversitesi, Sosyal Bilimler Enstitüsü, Yüksek Lisans Tezi, Rize.

Balcı, A. (2005). Sosyal bilimlerde araştırma. 5. Baskı. PegemA Yayıncılık, Ankara

Bayram, E. B. (2018). İlkokul 4. sını öğrencilerinin bilim insanı imajları ve bu imajların oluşmasında ders kitabı ve ögretmenlerin rolü. Yayımlanmamış Yüksek Lisans Tezi. Bayburt Üniversitesi, Sosyal Bilimler Enstitüsü, Bayburt.

Bertiz, H. (2005). Fen bilgisi ögretmen adaylarının yaratıcı dramaya yönelik tutumları ve öyküleme çalışmalarına ilişskin görüşleri. Yayınlanmamış Yüksek Lisans Tezi. Sosyal Bilimler Enstitüsü. Abant İzzet Baysal Üniversitesi, Bolu.

Bıkmaz, H. F., Aksoy, E., Tatar, Ö., \& Altınyüzük, A. C. (2013). Eğitim programları ve öğretim alanında yapılan doktora tezlerine ait içerik çözümlemesi (1974-2009). Eğitim ve Bilim, 38(168).

Büyüköztürk, Ş., K1lı̧ Çakmak, E., Akgün, Ö. E., Karadeniz, Ş., \& Demirel, F. (2012). Bilimsel araştırma yöntemleri. Ankara: Pegem Akademi.

Case, S. L. (1997). Implementation of cooperative learning: Teacher beliefs and attitudes. Unpublished doctoral dissertation. University of California, Santa Barbara, Santa Barbara, CA.

Chang, Y. H., Chang, C.Y., \& Tseng, Y. H. (2010). Trends of science education research: an automatic content analysis. Journal of Science Education and Technology, 19(4), 315-331.

Chun, S. (2000). An examination of relationship among science teaching actions, beliefs, and knowledge of the nature of science. Unpublished Doctoral Dissertation, Georgia University.

Cındıl, T., Özmen, H., \& Ünal, S. (2012). 7. sınıf fen eğitiminde tansiyon kavramının hikâyeleştirme yöntemi ile öğretiminin öğrencilerin başarılarına ve bilgiyi yapılandırmalarına etkisi. X. Ulusal Fen Bilimleri Ve Matematik Ĕ̈itimi Kongresi. Niğde.

Coşkun, H., Akarsu, B., \& Kariper, İ. A. (2009). Fen eğitiminde yapılandırmacı yaklaşım ve bilimsel öyküler. Erciyes Üniversitesi, Kayseri, Türkiye Alim Kitapları, 1-58. 
Coşkun, H. (2012). Bilimsel öyküler içeren eğitsel oyunlar ile fen öğretiminin öğrencilerin akademik başarısına etkisi. Yayınlanmamış Yüksek Lisans Tezi. Erciyes Üniversitesi, Eğitim Bilimleri Fakültesi, Kayseri.

Coşkun, H., Akarsu, B., \& Kariper, İ.A. (2012). Bilim öyküleri içeren eğitsel oyunların fen ve teknoloji dersindeki öğrencilerin akademik başarılarına etkisi. Ahi Evran Üniversitesi Kırşehir Eğitim Fakültesi Dergisi, 13(1), 93-109.

Çınar, B. (2016). Bilimsel gelişimin tarihsel süreçlerini içeren öykülerle fen derslerinin desteklenmesinin fene yönelik tutuma, bilim insan imajına, bilimsel süreç becerilerine ve akademik başarıya etkisi. Yayınlanmamış Yüksek Lisans Tezi. Sakarya Üniversitesi, Eğitim Bilimleri Enstitüsü, Sakarya.

Demirci, M. (2006). Öğrencilerin kuvvet konusunda kazandıklarl bilgileri güncel olaylarla ilişkilendirebilme düzeyleri. VII.Ulusal Fen Bilimleri ve Matematik Kongresi Özetleri, s.346.

Demircioğlu, H., Demircioğlu, G., \& Ayas, A. (2006). Hikâyeler ve kimya öğretimi. Hacettepe Üniversitesi Eğitim Fakültesi Dergisi (H.U. Journal of Education), 30, (110-119).

Dincel, M. (2005). Öyküleme ve deney tekniğinin fen bilgisi dersinde ögrrencilerin kavramsal anlama ve başarılarına etkisi. Yayınlanmamış Yüksek Lisans Tezi. Eğitim Bilimleri Enstitüsü. Marmara Üniversitesi, İstanbul.

Driver, R., Asoko, H., Leach, J., Mortimer, E., \& Scott, P. (1994). Constructing scientific knowledge in the classroom. Educational Researcher, 23(7), 5-12.

Ebbers, M. (2002). Science text sets: Using various genres to promote literacy and inquiry. Science Inquiry and Science Literacy, 80(1), 40-50.

Gómez, A. B. (2010). How to use tales for the teaching of vocabulary and grammar in a primary education English class. Revista española de lingüística aplicada, (23), 31-52.

Gölcük, A. (2017). Bilimsel hikâyelerle desteklenen fen eğitiminin öğrencilerin yaratıcllıkları ve duyuşsal özellikleri üzerindeki etkileri. Yayımlanmamış Yüksek Lisans Tezi. Hacettepe Üniversitesi, Eğitim Bilimleri Enstitüsü, Ankara.

Güler, T., \& Akman B. (2006). 6 yaş çocuklarının bilim ve bilim insanı hakkındaki görüşleri. Hacettepe Üniversitesi Eğitim Fakültesi Dergisi, 31, 55-66.

Gündüz, S. (2013). Öykü ve roman yazma sanatı. İstanbul: Toroslu Kitaplığ1 Yayınları.

Gür, K. M., \& Haktanır, G., (2007). Bilimsel anlatıda hikâyeleme tekniğine bir örnek: "tombul çekirdek ve anadolu yer sincabı (Gelengi)". İstanbul Üniversitesi İletişim Fakültesi 4. Uluslararası Çocuk ve İletişim Kongresi. 22-24 Ekim 2007,İstanbul. Bildiri Kitabı, s: 99-106.

Gürgen, G. (2009). Lisansüstü tezlerin topluma yararlılık ilkesi bakımından değerlendirilmesi. Ankara Üniversitesi Eğitim Bilimleri Enstitüsü IV. Lisansüstü Eğitim Sempozyumu.

İslamoğlu, H., Ursavaş, Ö., \& Reisoğlu, İ. (2015). Fatih projesi üzerine yapılan akademik çalışmaların içerik analizi. Ĕgitim Teknolojisi Kuram Ve Uygulama, 5(1).

İslamoğlu, A. H., \& Alnıçı, Ü. (2016). Sosyal bilimlerde araştırma yöntemleri. İstanbul: Beta Yayın Dă̆ıtım.

Karaçam, S., Aydın, F., \& Digilli, A. (2014). Fen ders kitaplarında sunulan bilim insanlarının basmakalıp bilim insanı imajı açısından değerlendirilmesi. On dokuz Mayıs Üniversitesi Eğitim Fakültesi Dergisi, 33(2), 606-627. 
Kılıç, T. E. (2019). Popüler bilim kitaplarının 6. sınıf öğrencilerinin fen bilimleri dersi akademik başarılarına, bilgilerinin kalıcılığına ve fenne yönelik tutumlarına etkisi. Yayımlanmamış Doktora Tezi. Gazi Üniversitesi, Eğitim Bilimleri Enstitüsü, Ankara.

Korkmaz, H., \& Kavak, G. (2010). İlköğretim öğrencilerinin bilime ve bilim insanına yönelik imajları. Ilköğretim Online, 9(3), 1055-1079.

Köklükaya, N., \& Yıldırım, E. G. (2015). Genel fizik laboratuvarı I dersinde bilimsel hikâyelerin kullanılmasına yönelik öğretmen adaylarının görüşleri. Eğitim ve Öğretim Araştırmaları Dergisi, 4(4).

Kutluca, T., \& Demirkol, M. (2016). Dicle Üniversitesi Ziya Gökalp Eğitim Fakültesi dergisinin bibliyometrik analizi. Dicle Üniversitesi Ziya Gökalp Eğitim Fakültesi Dergisi, 28, 108-118.

Kutluca, T., Birgin, O., \& Gündüz, S. (2018). Türk Bilgisayar ve Matematik Eğitimi Dergisi'nde yayımlanmış makalelerin içerik analizi bağlamında değerlendirilmesi. Turkish Journal of Computer and Mathematics Education, 9(2). 390-412.

Kuş, R. (2014). Biyoloji eğitiminde bilimsel hikayeler kullanmanın öğrenci tutumlarına etkisi. Yayımlanmamış Yüksek Lisans Tezi. Gazi Üniversitesi, Eğitim Bilimleri Enstitüsü, Ankara.

Lee, M.H., Wu, Y.T., \& Tsai, C.C. (2009). Research trends in science education from 2003 to 2007: A content analysis of publications in selected journals. International Journal of Science Education, 31(15), 1999-2020.

McLellan, H. (2007). Digital storytelling in higher education. Journal of Computing in Higher Education, 19(1), 65-79.

Merriam, S. B. (2013). Nitel araştırma: Desen ve uygulama için bir rehber. (3. Basım). Ankara: Nobel akademik yayıncılik.

Milli Eğitim Bakanlığı (MEB). (2013). İlkögretim fen bilimeri dersi öğretim programı. Ankara, Türkiye.

Milli Eğitim Bakanlığı (MEB). (2018). İlkögretim fen bilimleri dersi öğretim programı. Ankara, Türkiye.

Milne, C. (1998). Philosophically correct science stories? examining the 1mplications of heroic science stories for school science. Journal of Research In Science Teaching, 35(2), 175-187.

Okyay, Ö. (2015). Öykü yönteminin çocuklarda alıcı ve ifade edici dil ile bilimsel sözcük kazanımlarına etkisi. Yayımlanmamış Doktora Tezi. Gazi Üniversitesi, Eğitim Bilimleri Enstitüsü, Ankara.

Ören, F. Ş., \& Yılmaz, T. (2013). Fen ve teknoloji dersinde kavram karikatürleriyle desteklenmiş bilimsel hikâyeler temelli rehber materyal geliştirme çalışması. Eğitim ve Öğretim Araştırmaları Dergisi, 2 (2 ), 130-142.

Pekmezci, S. (2014). Bilişim teknolojileri destekli kısa hikayelerin öğrencilerin başarıları, özyeterlik algıları ve fene yönelik tutumlarına etkisi. Yayımlanmamış Yüksek Lisans Tezi. Pamukkale Üniversitesi, Eğitim Bilimleri Enstitüsü, Denizli.

Polat, M. (2011). Bilimin doğası hakkındaki görüşlerin kısa hikâyeler yöntemiyle değerlendirilmesi: Fen bilgisi öğretmen adayları örneği. Yayımlanmamış Doktora Tezi. Gazi Üniversitesi, Eğitim Bilimleri Enstitüsü, Ankara.

Polat, M., \& Taşar, M. F. (2013). Bilimin doğası hakkındaki görüşlerin değerlendirilmesinde alternatif bir yöntem: kısa hikâyeler yöntemi. Mersin Üniversitesi Eğitim Fakültesi Dergisi, 9(2), 259-274. 
Roach, L. E. (1993). Use of the history of science in a nonscience majors course: Does it affect students understanding of the nature of science?. Unpublished doctoral dissertation, Louisiana State University, Baton Rouge.

Saracaloğlu, A. S., Gündoğdu, K., Altın M., Aksu, N., Kozağaç, B. Z., \& Koç, B. (2014). Yaratıcı düşünme becerisi konusunda 2000 yılı ve sonrasında yayımlanmış makalelerin incelenmesi. Adnan Menderes Üniversitesi Ĕgitim Fakültesi Ĕgitim Bilimleri Dergisi, 5(2), 62-74.

Saraç, H., \& Kunt, H. (2016). Yapılandırmacı yaklaşım 7e öğrenme halkası modeli ile ilgili yapılan araştırmalar: içerik analizi çalışması. International Periodical for the Languages, Literature and History of Turkish or Turkic 11(9), 701-724.

Selim, G. (2013). Bilimsel dergilerin 7. sını öğrencilerinin bilimsel okuryazarlı̆̆ına ve fen ve teknoloji dersine yönelik tutumlarına etkisinin araştırllması. Yayımlanmamış Yüksek Lisans Tezi. Marmara Üniversitesi, Eğitim Bilimleri Enstitüsü, İstanbul.

Şen Gümüş, B. (2009). Bilimsel öykülerle fen ve teknoloji eğitiminin öğrencilerin fen tutumlarına ve bilim insanı imajlarına etkisi. Yayımlanmamış Yüksek Lisans Tezi. Hacettepe Üniversitesi, Sosyal Bilimler Enstitüsü, Ankara.

Tao, P. (2002). A study of students focal awareness when studying science stories designed for fostering understanding of the nature of science. Research in Science Education, 32, 97- 120.

Taşar, M. F. (2006). Probing preservice teacherse understandings of scientific konowledge by using a vignette in conjuction with a paper and pencil test. Eurasia Journal of Mathematics, Science and Technology Education, 2(1), 53- 70.

Tatar, E., Kağızmanlı, T. B., \& Akkaya, A. (2014). Türkiye'deki teknoloji destekli matematik eğitimi araştırmalarının içerik analizi. Buca Eğitim Fakültesi Dergisi, 35, 33-45.

Tavşancıl, E., \& Aslan, E. (2001). İçerik analizi ve uygulama örnekleri. Epsilon Yayınları: İstanbul.

Tolgay, N. (2018). Bilimsel öyküleme tekniğinin öğrencilerin fen ve teknoloji dersindeki akademik başarılarına ve derse ilişkin tutumlarına etkisi. Journal of Social And Humanities Sciences Research (JSHSR), 5(27), 2746-2752.

Türkmen, H., \& Ünver, E. (2012). Fen eğitiminde hikâyelendirme tekniği. Journal of European Education, 2(1).

Unat, Y.(2017). Bilim tarihinden örneklerle genç bilim insanlarına öneriler. Üstün Zekâlılar Eğitimi ve Yaratıcllik Dergisi, 4(1), 13-26.

Ünver, E. (2015). 5. sinıf ögrrencilerinin sindirim sistemindeki kavramları öğrenmede hikâyelendirme tekniğinin etkisi. Yayımlanmamış Yüksek Lisans Tezi. Ege Üniversitesi, Sosyal Bilimler Enstitüsü, İzmir.

Yar, M. (2017). Ortaokul öğrencilerinin bilim insanı, mucit ve mühendis hakkındaki görüşleri. Yayımlanmamış Yüksek Lisans Tezi. Abant İzzet Baysal Üniversitesi, Eğitim Bilimleri Enstitüsü, Bolu.

Yavuz, G., \& Yavuz, S. (2017). Fen eğitiminde proje tabanlı öğretimle ilgili tezlerin içerik analizi: Türkiye örneği (2002-2014). Mehmet Akif Ersoy Üniversitesi Eğitim Fakültesi Dergisi, 43, 255-282.

Yıldırım, A. (1996). Disiplinler arası öğretim kavramı ve programlar açısından doğurduğu sonuçlar. Hacettepe Üniversitesi Ĕ̆itim Fakültesi Dergisi, 12, 89-94. 
Yıldırım, A., ve Şimşek, H. (2011). Sosyal bilimlerde nitel araştırma yöntemleri. (8. Basım). Ankara: Seçkin Yayınları.

Yılmaz, T. (2013). Kavram karikatürleriyle desteklenmiş bilimsel hikayelerin öğrencilerin akademik başarıları, tutumları ve motivasyonları üzerine etkisi. Yayımlanmamış Yüksek Lisans Tezi. Celal Bayar Üniversitesi, Fen Bilimleri Enstitüsü, Manisa.

Yılmaz Korkut, T., \& Şaşmaz Ören F. (2018). Kavram karikatürleriyle desteklenmiş bilimsel hikâyelerin akademik başarı, tutum ve motivasyon üzerine etkisi. Batı Anadolu Eğitim Bilimleri Dergisi, 9(1), $38-52$.

Yücel-Toy, B. (2015). Türkiye'deki hizmet öncesi öğretmen eğitimi araştırmalarının tematik analizi ve öğretmen eğitimi politikalarının yansımaları. Eğitim ve Bilim, 40(178), 23-60.

Zengin, Ö. (2018). Bilim insanlarının çocukluk yaşantıları ve bilimsel kariyer süreçleri. Yayımlanmamış Yüksek Lisans Tezi. Recep Tayyip Erdoğan Üniversitesi, Fen Bilimleri Enstitüsü, Rize.

Zengin, Ö., \& Küçük, M., (2018). Meraklı zihinler kitabında yer alan bilim insanlarının özyaşam öykülerinin analizi. Turkish Journal of Teacher Education, 7(2).

Zorluoğlu, L. C., \& Elbir,Ç. B. (2019). Eğitsel oyuncak ve eğitsel oyun içerikli araştırmalardaki eğilimler: İçerik analizi. Bayburt Eğitim Fakültesi Dergisi, 14(27), 1-22. 


\section{EXTENDED ABSTRACT}

Today, studies in the field of science facilitate access to information and technology, as well as a change in the structure of societies. This change also plays a role in shaping the educational experiences of children. In recent years, with the aim of educating science literate individuals, it is noteworthy that scientific story method has been used in classrooms. In the learning environments enriched with appropriate techniques and learning tools by adding scientific stories that are familiar to the students could be provided effective learning. In this context, this study is a content analysis study which determines the tendency towards the use of scientific story method in science teaching in national literature. For this purpose, the following questions were sought answers in the studies examined:

-What is the distribution of the works according to the general characteristics (year, author, type of publication)?

-What is the distribution of the studies according to content characteristics (story types, aims, methods, data collection tools, number of data collection tools, participants, results and recommendations)?

In order to reach the publications examined in the study, databases were searched using the keywords "scientific story", "scientific narrative", "storytelling in science", "storytelling in science", "scientist", "story", " narrative " and "science teaching". Using these keywords, education journals, Higher Education Institution [YÖK] thesis database and TÜBİTAK ULAKBİM database were searched. In this respect, a total of 29 academic publications including 12 articles, 12 master's theses, 3 doctoral theses and 2 symposium presentations were reached. The classification matrix was used to analyze the studies obtained from the databases. First, the codes corresponding to each category are prepared. For example, each study was categorized by year of publication, type of publication, and number of authors. Subsequently, the studies were coded for purposes. Studies with common goals were grouped under the same code. Similar general purpose codes are combined and grouped under the theme name. Similar processes were followed in creating other codes and themes. This research is limited to publications such as articles, theses and conference papers conducted on scientific story in science teaching. Adhering to this limitation, databases were frequently checked to include current articles and theses related to the research. In addition, the data obtained from the research were examined by a language specialist and field education specialist. In this study, a scale was used as a data collection tool which was used in many studies. In the light of the findings, the fact that most of the studies examined in terms of general characteristics and content characteristics have been conducted in recent years shows that the tendency to use scientific story method in science teaching has increased. In addition, the studies were conducted with a few authors in the form of one or two persons. In addition, in the studies conducted on the scientific story; It was seen that the researchers 
mostly prepared their studies as master's thesis. When the studies are analyzed according to their aims, it is seen that many researchers aim to investigate the effect of scientific story method on academic achievement, attitude, motivation, self-efficacy, scientific process skills and retention of knowledge. In addition, it has been observed that many researchers aim to reveal the image of students as scientists. In a small number of studies, it is seen that researchers aim to teach concept by means of scientific story method. When the studies are analyzed in terms of research methods, it is seen that most of the researchers adopt quantitative research approach and conduct experimental studies under this approach. On the other hand, it is seen that among qualitative researches is predominantly used the phenomological method. Mixed method was preferred by a small number of researchers. In the studies, it was determined that the researchers preferred achievement tests, attitude and motivation scales more. Researchers prefered less interview, observation and researcher diaries as a data collection tool. On the other hand, it was observed that more than one data collection tool was used to collect data. Studies have shown that the majority of scientific stories are descriptive science stories. In addition, it was surprising that researchers did not prefer politically corrective science stories as the subject of their scientific stories. When the studies were examined in terms of the study groups, it was seen that middle school students and university students were preferred much more. When the results obtained from the researches are examined, it is seen that the use of scientific story method in science teaching increases the academic achievement, attitude and motivation of the students. It was also found that scientific story method developed students' skills such as self-efficacy, retention of knowledge and scientific process skills. Another result obtained from the studies is that the scientific story method changes and improves the scientist images. When the studies examined the suggestions; it was determined that the suggestions were mostly related to the use of scientific story method as a learning and teaching approach, strategy, method and technique in classrooms. As a result of the research, the following suggestions can be given: In future studies, qualitative and mixed approach methods could be preferred, and the quality of the research can be increased by using interview, observation, drawing, diary, group interview or in addition to quantitative data collection tools. As a participant, the number of studies on primary school students and teachers can be increased. Studies related to scientific story method can be done in preschool science teaching. 